\title{
O DIREITO INTERNACIONAL SANITÁRIO E SEUS TEMAS: APRESENTAÇÃO DE SUA INCÔMODA VIZINHANÇA
}

Guido F. S. Soares (*)

\section{INTRODUÇÃO}

Neste final de século, as tendências de o Estado cada vez mais assumir funções regulatórias em campos crescentes da vida da sociedade, que começaram a ser vislumbradas no final do século XIX, com a Revolução Industrial, se tornam de tal maneira patentes que passam a configurar as funções normais do Poder Público. No modelo de organização societária que imperava nos séculos imediatamente anteriores ao atual, ou seja, do État Gendarme, os Poderes Públicos agiam qual um desarmado policial de quarteirão, que somente interviria com o ủso dos poderes coercitivos (inclusive com os poderes de intervenção através de normas regulamentares), no caso de grave perturbação da ordem pública, e com a finalidade de estabelecer uma ordem natural que as forças do mercado livre deveriam regular. $\mathrm{Na}$ filosofia do mais puro liberalismo, o campo de atuação do Estado era deixado, preferencialmente, para ocasiões excepcionais, quando a iniciativa privada era inoperante ou quando seu exercício viesse a causar malefícios a toda a sociedade. Assim, os temas relacionados à saúde constituiam um assunto deixado à iniciativa particular, portanto, sob o jogo livre das forças do mercado, onde nem sempre os incentivos capitalistas motivariam uma ação dos particulares em face das necessidades sociais.

O conceito de saúde pública, entendida como o propiciamento de condições mínimas de sanidade, e enquanto um conjunto de obrigações que deve incumbir ao Estado, mal caberia em tal concepção de organização societária, onde 0 intervencionismo estatal era olhado com desconfiança. Conforme se pode observar na história dos séculos anteriores, somente em si-

(*) Professor Titular de Direito Internacional Público da Faculdade de Direito da USP. Ministro Conselheiro do Quadro Especial da Carreira Diplomática do Brasil, tendo servido inclusive na Missāo Permanente do Brasil junto à Organizaçāo das Nações Unidas e outras organizaçōes sediadas em Genebra, tendo sido Delegado brasileiro em várias reuniōes da Organização Mundial da Saúde e integrado a Delegaçāo brasileira nas sessōes de 1995, 1996 e 1997 da Assembléia Mundial da Saúde. 
tuações de extrema necessidade, tais como durante os surtos de epidemias (os vários surtos de peste negra ou de cólera, na Europa), ou em ocasiões de imediato pós-guerra, ou ainda de falta de alimentos, o Estado se permitiria intervir no mercado, estabelecer normas de controle de atividades produtivas, de movimentos de pessoas e bens e de algumas outras atividades relevantes na sociedade, sempre com a idéia de que o campo da regulamentação da economia era um assunto que não deveria caber nas funções do Governo; por outro lado, a idéia fundamental era de que o intervencionismo deveria cessar tão logo cessassem as condições que teriam motivado a intervenção do Estado.

A nossos olhos, de homens do século $X X$, circundados por um Estado com poderes intervencionistas cada vez mais abrangentes e poderosos, pareceria absurdo pensar que os hospitais, a previdência social, a higiene pública (inclusive os serviços de tratamento de águas servidas, de esgotos e de lixo doméstico ou hospitalar) seriam campos onde o Estado não deveria intervir! De igual forma, a regulamentação jurídica do trabalho, tanto no que respeita às próprias relações entre empregado e empregador quanto às condiçōes de sanidade do tipo e do local do trabalho, era assunto deixado à livre pactuação entre os interessados, sem que o Estado se desse conta da necessidade de sua intervenção, num campo minado por extrema injustiça, onde as negociações se davam entre pólos totalmente desiguais.

Acreditamos que a emergência de um Direito Sanitário, como um corpo de regras de Direito Público e sistematizadas, coincide com a instituição do Estado do bem-estar (Welfare State), com seus poderes regulatórios cada vez mais abrangentes, a ponto de englobar todos os aspectos da vida societária. As explicações para o fenômeno do agigantamento da esfera dos interesses públicos, em detrimento de um sistema jurídico voltado à proteção prioritária dos interesses dos particulares, a nosso ver, devem ser buscadas numa tendência secular de o poder, inerentemente, concentrar-se cada vez mais, de parcela em parcela cedida pelos particulares, num jogo de cessão de liberdades individuais, em benefício da atuação do Estado(1); por outro lado, ao término de uma situação catastrófica que tinha exigido a intervenção decisiva dos Poderes Públicos (como foi caso das duas guerras totais do século $X X$ ), os indivíduos e empresas particulares não pensaram em retomar aquelas parcelas de poder que tinham cedido ao Estado, em caráter de urgência, ou não teriam condições de fazê-lo ${ }^{(2)}$.

(1) Veja-se, de Bertrand de Jouvenel, "Du Pouvoir, Histoire Naturelle de sa Croissance", Paris, Hachette, 1972.

(2) O fato de as autoridades públicas saírem com poderes cada vez mais extensos após acontecimentos traumáticos, como foram as guerras totais do século $X X$, encontra-se muito bem fundamentado em Julien Freund, "L'Essence du Politique", Paris, Sirey, 1985, que se apóia na observaçāo de que parcelas de poderes acrescidas ao Estado, e que passam a integrar o campo do "comando da autoridade", correspondem a parcelas de "obediência" que os individuos lhe cederam, portanto, uma explicaçāo dialética da origem do poder. 
Como já observamos em trabalho anterior ${ }^{(3)}$ : " $E$ de todo interesse observar que a pessoa que reconheceria de maneira clara e objetiva tal crescimento secular do poder seria, não um Stalin ou um Mao Tsé-Tung, ou um dirigente de um pais sem um Legislativo respeitável ou de fachada, mas nada menos do que um dirigente de um Estado, modelo do capitalismo, o Presidente Harry Truman, dos EUA, que teria dito, em 1953, que os poderes do Presidente fariam um Cesar, Gengis Kahn ou um Napoleão 'roer as unhas de inveja' ("bite his nails with envy')" (4).

Entenda-se, pois, o Direito Sanitário como um conjunto de normas, que, na concepção corrente do Direito, cabe como obrigação institucional ao Estado, restando a esfera de atuação dos particulares como um campo residual, a qualquer momento reivindicável pelos Poderes Públicos. Tal é a conseqüência do intervencionismo atual do Estado em qualquer setor da vida societária, em particular no que se refere à saúde pública, que a maioria das Constituições modernas considera, textualmente, como campo prioritário dos Poderes Públicos.

Por outro lado, o Direito Sanitário não pode deixar de sentir as influências de fenômenos que têm marcado sua emergência, e que são o traço característico do século XX: a internacionalidade, ou como tem sido, nos últimos anos, denominada: a globalização. As extraordinárias facilidades de transportes, se por um lado propiciam um movimento internacional de pessoas e mercadorias, facilitam, igualmente, as transmissões de doenças; a tecnologia industrial, a um ritmo desenfreado, polui rios e lençóis freáticos transfronteiriços e lagos internacionais, e a regutamentação de seus efeitos no meio ambiente se torna uma questão a ser resolvida em nível internacional. Os inacreditáveis avanços das telecomunicações, ao lado de seus efeitos benéficos, igualmente internacionalizam padrões culturais de culto à violência, ao consumerismo e à boçalidade nos padrōes comportamentais, com reais efeitos quanto ao espraiamento de problemas psicossociais (sem que se difundam, paralelamente, as técnicas de lidar com eles, conforme existentes nos paises de exportação daquela banalização da violência, do consumerismo e da vulgaridade cultural). Globalização, em tal sentido, significaria duas realidades concomitantes, que decisivamente têm influído em todos os campos juridicos: a) uma invasividade das regulamentações jurídicas em todos os campos da vida em sociedade (como já se apontou, conseqüência do crescimento secular do poder do Estado), portanto, um fenômeno de horizontalidade, e b) uma quebra das distinções entre as esferas juridicamente regulamentadas, no que respeita aos fatores interno e internacional, ou seja, na atualidade, encontram-se esmaecidos os poderes domésticos dos Estados, em favor de normas originárias de fontes internacionais,

(3) Guido F. S. Soares, "Os Órgãos das Relações Exteriores dos Estados e as Formas de Diplomacia na Atualidade", in Revista da Faculdade de Direito da USP (no prelo).

(4) Citação apud Louis Henkin, "Foreign Affairs and the Constifution", Nova York, The Norton Library, W. W. Norton \& Company Inc., 1975, p. 278. 
as quais tendem a regular assuntos que, tradicionalmente, eram deixados à competência das autoridades internas, portanto, um fenômeno de verticalidade, onde os campos de atuação do direito interno tendem a ser cada vez mais internacionais, seja porque o mercado interno hoje é um mercado internacional, seja porque o homem da atualidade é um homem do mundo, ou ainda porque o próprio assunto regulado, como o meio ambiente ou as condiçōes sanitárias, mesmo em nível local, são fenômenos globais.

\section{OS ANTECEDENTES HISTÓRICOS E A EMERGÊNCIA DO DIREITO INTERNACIONAL SANITÁRIO}

Se as normas do Direito Sanitário nos sistemas juridicos internos são relativamente modernas, como se demonstrou, coincidentes, na História, com o intervencionismo estatal, as normas internacionais que regulam a saúde pública, em nivel mundial, são típicas do século $X X$, elaboradas, precisamente, após a Primeira Guerra Mundial de 1914-18 e já dentro das características renovadas do Direito Internacional.

Na História, há alguns exemplos isolados de relações internacionais entre as unidades políticas independentes, assimiláveis aos modernos Estados $^{(5)}$ na esfera da saúde pública. Autores citam os exemplos de tratados bilaterais entre a Sereníssima República de Veneza e seus vizinhos, no século XIV, no relativo a providências quanto a medidas de contenção das denominadas moléstias quarentenárias, ou seja, aquelas que impunham a navios mercantes uns quarenta dias de obrigações de estar ao largo dos portos venezianos, bem como a criaçăo de lazaretos (com finalidades de observação e tratamento de pessoas), sem que, com tais providências, se pudessem invocar restrições à liberdade de navegação pelos mares de então, ou ações unilaterais das autoridades públicas, em função da proteção de navios nacionais. Conquanto a idéia de contágio ainda não estivesse cientificamente estabelecida, sua idéia já se propunha ao público e aos médicos, que, não podendo curar aquelas doenças, forçaram as autoridades a adotar medidas de oposição à sua transmissão interpessoal. Mesmo em situações catastróficas, como os vários surtos de peste negra (a peste bubônica, que foi importada, na Europa medieval, da Mongólia, pela Rota da Seda) que avassalaram vários países da Europa na Idade Média e nos séculos XV e XVI, e

(5) Na verdade, somente se poderia falar de Estado, esta forma de organização da sociedade civil em que existe uma imbricação inseparável entre um território relativamente bem delimitado, uma população relativamente homogênea e uma autoridade incontrastável (soberania), como tal reconhecida por entidades com iguais atributos, a partir do momento histórico em que emergiu; os primeiros Estados nacionais, como Espanha, Portugal e os outros Estados europeus, precisamente a partir de 1648, Paz de Vestfália, que reconheceria a supremacia do poder dos governantes leigos sobre qualquer outro tipo de organização, onde o poder estivesse dífuso entre outros titulares. Assim sendo, tanto as cidades gregas como as unidades em que o mundo medieval se fragmentou, como as cidades do norte da Itália ou do norte da Alemanha, são denominadas "cidadesEstados", por sua similitude com os Estados modernos. 
as grandes epidemias de cólera de 1829-37, 1844-55, 1865, 1883-87 e 1892, certamente por desconhecimento científico dos fenômenos de transmissão internacional dos agentes patológicos. As providências de prevenção internacional concertadas entre os Estados, nas tentativas de evitar a propagação das doenças, pelo menos até meados do século XIX, foram mínimas e tomadas em nivel local.

Destaque-se que, por volta do início do século XIX, praticamente todos os países europeus já haviam adotado' medidas legislativas internas no referente a uma administração de assuntos de saúde pública. Na verdade, em particular quanto a epidemias de doenças ditas pestilenciais de origem exótica, os modelos da legislação sanitária interna de um país passaram a ser copiados por outros, sem que houvesse consciência de uma cooperação internacional entre os Estados (naquele período, no exercício de uma diplomacia clássica, compativel com um État Gendarme, de regulamentação da paz, com o desconhecimento de qualquer outro assunto que não significasse a manutenção de um status quo). Se pode ter havido algum efeito internacional, este teria sido propiciado pela circulação das informações científicas (diga-se, bastante lentas) ou das vivências pragmáticas de cada Estado para além das fronteiras, com poucos incentivos por parte dos Estados: na verdade, as medidas de caráter prático quanto a ações concretas serão elaboradas em foros internacionais, de maneira assisternática e de maneira gradual, conforme se dirá a seguir.

Autores consultados, dos quais se destaca o Prof. Cino Vitta, em curso de 1933 na Academia de Direito Internacional da Haia(6), considerado o primeiro estudo na matéria, indicam os esforços do Imperador Louis Bonaparte, que, em 1851, convocou uma primeira conferência internacional sanitária, a qual acabaria por adotar uma Convenção internacional em 3 de fevereiro de 1852, firmada por alguns Estados do Mediterrâneo, no intuito de combater a peste, a cólera e a febre amarela, no estrito respeito às normas de liberdade de navegação naquele mar interior (e evitar as medidas drásticas e unilaterais dos Estados, com exigências quarentenárias abusivas, por vezes atentatórias às liberdades de livre circulação marítima, e que pudessem mascarar políticas de proteção a navios nacionais). Em que pese nunca ter entrado em vigor, a Convenção de 1852 representa um interesse particular, por haver reconhecido determinados princípios, que passaram a ser consagrados pelas legislaçōes dos Estados, como a obrigação de um Estado oficialmente declarar a existência de uma doença epidêmica em seu território (origem da declaração oficial de infecção), a obrigatoriedade de os navios estarem munidos de uma patente de saúde, limitaçōes da duração de quarentenas, e a obrigação da indicação de um agente sanitário responsável em determinados portos marítimos; constava em tal Convenção, igualmente, como anexo, uma tentativa de um código sanitário internacional, no que 
respeita a moléstias quarentenárias, então indicadas, e que compreendiam uma descrição das patologias e a indicação de meios práticos de evitar sua propagação.

Até 1892, seguiram-se outras conferências sanitárias internacionais, sem que, contudo, nenhuma outra convenção tivesse sido adotada entre os Estados participantes, diga-se, alguns paises da Europa; naquela data, reuniu-se em Veneza uma conferência internacional contra a cólera, e que celebraria uma convenção sobre o regime sanitário aplicável a navios de passagem pelo Canal de Suez (medidas de prevenção contra aquela doença originária do Oriente). Ainda contra a cólera, que por volta de 1890 penetraria na Europa pela então Pérsia e pelo Afeganistão e que devastaria a Rússia, a Alemanha e o interior da França, formou-se uma nova convenção, numa conferência sanitária reunida em Dresden, que estipularia as medidas a serem tomadas pelos Estados europeus, a qual repetiria os termos daquela de 1852: destaque-se a instituição de uma obrigação aos Estados contratantes de denunciar a aparição da cólera em seus territórios e a enumeração das medidas profiláticas a serem adotadas, bem como a interdição do fechamento das fronteiras terrestres, marítimas ou fluviais dos Estados (tendo-se permitido, contudo, a proibição da entrada de pessoas atingidas pela doença); reafirmando o espírito da precedência das normas sobre a liberdade do comércio internacional, a convenção claramente evitava qualquer medida que pudesse representar qualquer entrave ao comércio de mercadorias. Enfim, no final do século XIX, duas outras convenções sanitárias internacionais foram assinadas: uma em Paris, em 1894 (medidas internacionais de combate à cólera. em particular com relação a viajantes que se dirigiam às peregrinações a Meca) e a de Veneza de 1897, contra a peste negra (que então experimentava um surto epidêmico em Bombaim, na Índia), bem como foram, no período, realizadas várias conferências sanitárias internacionais em cidades européias.

As tentativas de melhor realizar a coordenação das atividades dos órgãos sanitários internacionais e/ou nacionais propiciariam a convocação em 1903, em Paris, da $11^{\text {a }}$ Conferência Internacional Sanitária, em particular no que se referia a melhor disciplinar as medidas internacionais de combate à peste e à cólera, reguladas em convenções distintas, e com o objetivo de fundir as normas esparsas num único documento internacional e redigir um código sanitário internacional. Deve-se notar que em tal conclave sanitário estiveram presentes Estados não europeus, como o Brasil, os EUA, e mais o Egito e a Pérsia, significativamente inaugurando a participação do Continente americano (o "Novo Mundo", como se dizia na época) em assuntos da política internacional global, em matéria sanitária. A Convenção assinada em 3 de dezembro de 1903 estipulava medidas internacionais de combate à peste e à cólera, conquanto parciais, e num de seus artigos finais recomendava aos Estados signatários adotar medidas contra a febre amarela, em modificação aos respectivos regulamentos internos sanitários, a fim de 
incluir medidas de combate aos mosquitos, definidos como os vetores dos germes dessa moléstia. Nos seus dispositivos, aperfeiçoou normas internacionais existentes no que se refere a medidas contra a invasão da peste (redução do período de observação ou de vigilância a cinco dias), e sobretudo as providências de combate aos ratos, então reconhecidos como vetores da peste bubônica, e a instituição do dever de os Estados velarem pela desratização dos navios merçantes. A citada Convenção incumbia ao Governo de França instituir um Escritório Internacional de Higiene Pública (Office International d'Hygiène Publique), com sede em Paris e que seria mantido por uma modesta contribuição dos Estados partes da Convenção, o que de fato se deu, em 1907 (Acordo de Roma, assinado pelos mesmos Estados signatários da Convenção de 1903, portanto, Estados da Europa, mais o Brasil e os EUA, tendo recebido, posteriormente, a adesão dos seguintes Estados americanos: Argentina, Bolívia, Chile, Canadá, México, Peru e Uruguai).

O novo organismo internacional era composto de um Comitê Permanente composto de delegados representantes técnicos dos Governos dos Estados-Partes, assistido por um Diretor-Geral e um Secretário-Geral, com atribuições de intermediar entre os Estados uma troca de informações de caráter geral de interesse da saúde pública, em especial aquelas de combate aos meios de transmissão e de profilaxia da peste, da cólera e da febre amarela. Desde sua instalação, o Escritório estendeu seu interesse para além das moléstias quarentenárias, para incluir os campos da salubridade de gêneros alimentícios, da higiene ambiental e da construção e administração de hospitais. $\mathrm{Na}$ verdade, por tratar-se de uma organização internacional ainda embrionária, com funções de mera difusão de conhecimentos e de ser um foro de intercâmbio de informações, com um orçamento restrito, sua atividade estava restrita a campos técnicos, sem grandes possibilidades de atuação direta em situações emergenciais.

Na verdade, conforme bem observou $R$. Dujarrie de La Rivière: "foi somente após o fato de os métodos pasteurianos terem esclarecido a epidemiologia das moléstias infecciosas e, em seguida, terem precisado sua profilaxia, é que se tornou possivel partir para esrabelecer-se uma profilaxia internacional: com base em fatos precisos, um acordo [entre Estados ou entre autoridades sanitárias de vários Estados] se fornava mais fácil e as conferências [internacionais] que se sucederam, puderam, então, produzir üteis resultados"(7). A necessidade da cooperação diutuma entre os Estados já despontava como uma das exigências de um mundo que começava a tornar-

(7) R. Dujarric de La Rivière, "Prophylaxie Nationale et Internationale des Maladies Épidémiques", Paris, Éditions Médicales Flammarion, 1948, p. 173, por nós traduzido, com termos adicionados, conforme texto citado apud Antoine H. Zarb, in "Les Institutions Spécialisées du Système des $\mathrm{Na}$ tions Unies et Leurs Membres", Paris, Editions Pedonne, 1980, p. 43. 
se pequeno, com os progressos dos transportes e das telecomunicações, e a melhor forma de traduzir esforços em comum começava a aparecer, que seria na instituição de entidades internacionais especializadas, numa superação da idéia de que a saúde pública seria assunto reservado às autoridades domésticas dos Estados.

\section{CARACTERISTICAS DAS RELAÇÕES INTERNACIONAIS NO SÉCULO XX: NOVOS FOROS DE NEGOCIAÇÕES E NOVOS ATORES INTERNACIONAIS NA CENA INTERNACIONAL}

Consideramos que o século $X I X$, na realidade, teria seu término, em 1919, com a Paz de Versalhes, que colocou um fim à Primeira Guerra Mundial de 1914-1918 ${ }^{(8)}$. Mais que a cronologia, os fatos apontam para uma substancial diferença nas relações internacionais do século $X I X$ e no século $X X$, estas, inauguradas num novo estilo, a partir daquela Paz. O século XIX ainda estava permeado da noção da soberania absoluta dos Estados, e como conseqüência, o Direito Internacional seria um direito de natureza contratual segundo o qual os Estados, soberanamente, cediam parte de seu poder, em função de normas de caráter proibitivo (ou seja, os Estados soberanos tudo poderiam, à exceção daqueles comportamentos expressamente proibidos pelo Direito Internacional, que eles, contratualmente, elaboraram com outros Estados de igual importância política!). Ainda tinham a maior relevância as relaçōes diplomáticas bilaterais clássicas, embora, a partir dos Congressos de Viena de 1824, já começassem a tornar-se mais freqüentes as reuniões dos Estados, em congressos internacionais, colocando em prática a diplomacia multilateral, na sua subespécie de congressos ou conferências internacionais $^{(9)}$, que, de reuniōes solenes e esporádicas em séculos anteriores

(8) Tanto a Primeira Guerra Mundial de 1914-1918, também denominada "a Grande Guerra", quanto a Segunda Guerra Mundial de 1939-1945, têm sua diferença, em relação às guerras dos séculos anteriores, por terem sido "guerras totais": nāo unicamente pela extensão geográfica dos campos de batalha, localizados em vários continentes, como pela extensāo das destruiçōes, que não distinguiram entre objetivos civis ou militares (uma vez que as indústrias localizadas na retaguarda passaram a ser alvos militares, dada a expressiva dependéncia da indústria militar da indústria civil) $\theta$, sobretudo pela falta de distinção entre o pessoal a serviço de Marte e a população civil (o que trazía uma equalização entre objetivos militares $\theta$ objetivos civis). Veja-se nossa tese de doutoramento em Ciências Humanas (Política Internacional), defendida na PUC-SP, em 1974, "Contribuição ao Estudo da Política Nuclear Brasileira".

(9) A diplomacia multilateral pode adotar basicamente duas formas: a) congressos ou conferências internacionais, convocados por um Estado ou por uma organização intergovernamental e regidas por normas especialmente votadas na ocasiāo; b) as reuniões ordinárias ou extraordinárias das organizaçōes internacionais intergovernamentais, também denominadas diplomacia parlamentar, regidas por normas institucionais anteriormente elaboradas pelas próprias organizações. Em geral, nos congressos ou conferências adotam-se instrumentos internacionais solenes, como tratados ou convençōes internacionais, ao passo que nas reuniões das organizaçōes intergovernamentais ora podem ser adotados atos normativos com denominação e força normativa segundo $o$ disposto nos estatutos das mesmas, ora podem ser adotados, através de procedimentos especificos, tratados ou convençōes internacionais. Veja-se, mais além, o caso da Organização Mundial da Saúde. 
(em particular por ocasião da adoção de grandes tratados de paz), passaram a ter menos pompa e mais freqüência no tempo, abrindo, inclusive, a participação a técnicos governamentais ou universitários, ao lado dos diplomatas, os tradicionais negociadores em nome dos Governos.

Importa notar que, mesmo que muitos dos tratados ou convenções adotados nas conferências sanitárias internacionais desse período anterior ao pós-guerra 1914-1918, não fossem posteriormente ratificados pelos Estados participantes, e ainda, mesmo que não se chegasse a concluir qualquer ato internacional relevante durante aquelas reuniōes internacionais, deve ressaltar-se o fato de que aqueles congressos e conferências internacionais em matéria sanitária elaboraram normas técnicas, muitas das quais provenientes de experiências normativas internas dos Estados, e que serviriam de modelo para futuras providências normativas internacionais. Assim, como será visto, o fato é que as atuais normas do Regulamento Sanitário Internacional, elaboradas sob a égide da Organização Mundial da Saúde, resultaram de uma experiência histórica acumulada, em particular, em congressos e conferências diplomáticas do século anterior, onde se nota uma progressiva mudança de enfoques político-diplomáticos, para uma postura técnica, advinda da participação de órgãos governamentais, científicos ou universitários especializados em matéria de saúde pública e controles sanitários. Por outro lado, ainda que as regras técnicas internacionais assim adotadas não ganhassem um status de normas jurídicas internacionais, as discussões e eventuais recomendações, bem como a troca de experiências entre funcionários governamentais, já representariam importantes fatores para a disseminação de informações técnicas e científicas em matéria de controles de doenças, sobretudo em caso de epidemias, que os Estados, certamente, acabariam por incorporar na sua prática diuturna e adotar como normas de sua legislação sanitária interna.

O mundo reorganizado após a Grande Guerra de 1914-1918 viria a consagrar um sistema de relações internacionais, cujas notas características mais fundamentais ainda perduram: a instituição de organizações internacionais intergovernamentais, de caráter permanente, com uma personalidade jurídica clara e distinta dos Estados, mesmo daqueles que as integram, e poderes normativos, em algo assimilados àqueles inerentes aos Estados. Portanto, a tipicidade das relações internacionais de todo o século XX passaria a residir na extraordinária importância atribuída à diplomacia multilateral, ao lado da especialização de foros negociadores para assuntos específicos, deixando os magnos assuntos políticos de resguardo da paz para organizações cimeiras permanentes, onde se pretende haver uma representatividade universal de todos os Estados da atualidade, independentemente de seu poder político, econômico ou outro. De europeu, o Direito Internacional começaria, após a Paz de Versalhes, para encontrar-se com sua vocação de ser verdadeiramente universal (conquanto, em 1919, ainda persistissem os bolsões colonialistas na África e Ásia, aos poucos desmon- 
tados, até chegar-se a um universalismo de representatividade de todos os Estados na atualidade da ONU).

Já havia, em 1919, alguma experiência internacional da diplomacia multilateral herdada do século XIX, em particular no Continente americano (a existência da União Panamericana, antecessora da atual OEA) e na existência, em nivel global, das denominadas "uniōes administrativas" estabelecidas no final daquele século. Conforme escrevemos em artigo a ser publicado na Revista da Faculdade de Direito da USP:

De fato, a partir de 1889 , as tendências de maiores contactos comerciais com os vizinhos, como exigia o espírito pragmático dos norteamericanos, juntamente com os ideais compartilhados dos jovens Estados de fala espanhola, subjacentes na sua cultura e de extrema relevância como fator de aglutinação, os quais aspiravam à instituição de uma grande federação dos povos que tinham valores comuns forjados a partir de aspiraçōes e heróis comuns, unificados pela história da luta contra a colonização espanhola, encontraram-se com a necessidade de um Brasil republicano, urgentemente interessado em aproximar-se das Nações independentes do Continente. Aproveitando-se de uma incipiente experiência de aproximação com os seus vizinhos, que então se realizava através de um Escritório Comercial do Governo, em Washington, os EUA convocariam nos últimos anos do Século XIX, naquela Capital, uma grande conferência panamericana, da qual sairia fundada a primeira organização intergovernamental da história, a então denominada União Panamericana, antecessora da atual Organização dos Estados Americanos.

Um esclarecimento sobre a denominação da primeira organizaçăo intergovernamental, a União Panamericana, revela a verdadeira vocação das atuais organizações internacionais, e as raízes de um tipo de diplomacia que então se criava: a diplomacia multilateral do subtipo parlamentar, que analisaremos logo mais. No final do Século XIX, algumas experiências de uniões pessoais e reais entre Estados estavam presentes aos espíritos da época: a união pessoal entre Escócia e inglaterra, para a constituição da Grã-Bretanha ou a união entre Áustria e Hungria, com a conformação do Império Austro-Húngaro (uniões realizadas através de casamentos entre famílias de nobres reinantes nos países da União). Por outro lado, pelo menos duas séries de importantes experiências, no caso de uniões reais, realizadas por tratados entre Estados, se apresentaram, coetaneamente à criaçâo da União Panamericana em Washington: a) em primeiro lugar, a realização de uma política intemacional de uniformizar e harmonizar as legislações internas dos Estados, em matéria de propriedade intelectual: a constituição da União de Paris para a proteção da propriedade industrial, a 1883, da União de Berna para a proteção das criações artísticas e literárias, a 
$1886^{(10)}$ e b), as necessidades de maior coordenação dos serviços especializados dos Governos, em matéria de uniformização de normas técnicas nacionais em matéria de correios e em matéria de telecomunicações, sobretudo na distribuição eqüitativa do espectro de ondas hertzianas por entre os Estados unionistas, e portanto a instituição, em Berna, da União Postal Universal, em Genebra, da União Internacional das Telecomunicações. Neste último caso das denominadas uniões administrativas do final do Século $\mathrm{XIX}$, a idéia era de que os Estados unionistas declaravam-se numa uniẫo, entidade com alguns traços $\mathrm{e}$ atributos de personalidade jurídica própria (e devemos dizer que a noção de organização internacional com plena personalidade jurídica, é uma criação do Tratado de Versalhes de 1919, que instituiu a Sociedade das Nações e a Organização Internacional do Trabalho, primeira instituição a levar o nome de "organização internacional"), estabeleciam mecanismos de decisões em conjunto, em encontros dos Estados Partes em intervalos espaçados no tempo, e uma secretaria de mero apoio logístico, de natureza permanente, e com sede num país, que cortesmente ofereceria os próprios funcionários para tais tarefas. Aos poucos, aquelas Secretarias de apoio logístico ganham relevância, exigindo funcionários internacionais e despregados de liames de nacionalidade, com vínculos próprios com as Uniões, as reuniões espaçadas se adensam no tempo, acabando por exigir a constituição de órgãos decisórios permanentes, compostos de representantes diplomáticos dos Estados. Foi necessário esperar pelo final da Segunda Guerra Mundial, para que a União Panamericana, a União Postal Universal e a União internacional das Telecomunicações ganhassem a forma definitiva das organizações internacionais atuais (devendo observar-se que as duas últimas uniões, guardam até hoje sua denominação originária, e que a União Panamericana foi rebatizada de Organização dos Estados Americanos, por ocasião da adoção de sua atual Carta, a 30 de abril de 1948, quando da IX Conferência Interamericana, e não mais "panamericana", em Bogotá) e que as Uniões de Paris e de Berna encontrassem uma expressão de modernidade, federandose sob a égide da Organização Mundial da Propriedade Intelectual, a OMPI, com sede em Genebra (Guido F. S. Soares, "Os Órgãos..." cit., no prelo).

É necessário dizer que, da mesma forma como os países da Europa sentiram a necessidade de cooperação internacional em matéria sanitária,

(10) Vejam-se nossos artigos: "Antecedentes da Transferência Internacional de Tecnologia", in Revista de Direito Mercantil, São Paulo, ano 24, jan./mar. 1985, pp. 19 e ss., e "O Tratamento de Propriedade Intelectual no Sistema da Organização Mundial do Comércio: Uma Descrição Geral do Acordo 'TRIPS' ", in Revista de Direito Civil, Imobiliário, Agrário e Empresarial, São Paulo, Faculdade de Direito da USP, 1995, pp. 98/112. 
com a fundação, em 1907, em Paris, do Escritório Internacional de Higiene Pública, o Continente americano se antecipara nos primeiros passos daquela cooperação internacional, na sua forma institucionalizada, com a instituição da primeira entidade intergovernamental dedicada a assuntos sanitários internacionais, que emergiria na História. Com efeito, por ocasião da II Conferência Panamericana, em 1902, fundava-se, com sede em Washington, uma Repartição Sanitária Panamericana, constituída por uma Conferência (reuniões a cada 4 anos), um Conselho Diretor (reunião pelo menos uma vez ao ano), uma Comissão Executiva do Conselho Diretor (reuniões a cada seis meses) e a Repartição Sanitária Panamericana (o secretariado do organismo), dirigida por um Diretor. Após sucessivas reformas, tal entidade hoje se denomina Organização Panamericana de Saúde, continua com sua sede em Washington, é uma organização especializada do sistema da OEA (acordo com a OEA firmado em 1949) e dentre suas finalidades de promover "a coordenação dos esforços dos países do Hemisfério Ocidental para combater as enfermidades, prolongar a vida e estimular o melhoramento físico e mental de seus habitantes (art. $1^{2}$ de sua Constituição)", podem mencionar-se: "evitar a invasão e propagação de enfermidades; estimular e apoiar as campanhas governamentais contra endemias e epidemias: promover a cooperação na esfera da higiene pública; fornecer prontas informações aos Governos americanos sobre doenças sujeitas a quarentenas; realizar estudos e divulgar informaçōes relativamente a assuntos de sua competência"(11). Destaque-se que, na atualidade de nossos dias, onde, em assuntos de Direito Sanitário Internacional, sobreleva a presença e atuação da Organização Mundial da Saúde, a Organização Panamericana de Saúde serve como o seu órgão regional, em virtude do Acordo de Washington firmado em 24 de maio de $1949^{(12)}$.

No que se refere ao campo normativo, sob a égide da então Repartição Sanitária Panamericana, foram convocadas várias Conferências Sanitárias Panamericanas, durante as quais importantes convenções foram adotadas das quais se destacam: a primeira Convenção Sanitária de Washington de 1905 (em grande parte inspirada na Convenção de Paris de 1903), reformulada em 1912, e, após a Primeira Guerra Mundial, o Código Sanitário Panamericano de 1924 em Havana. A experiência de tais convenções panamericanas representa um particular interesse para o estudo do Direito Internacional Sanitário, na medida em que procuraram adaptar as regras já convencionadas em nível internacional (pelo menos no continente europeu) a uma realidade de paises com parcos recursos financeiros, mas com uma rica experiência no combate e na prevenção de doenças tropicais, nomeadamente a febre amarela.

(11) Hildebrando Accioly, "Tratado de Direito Internacional Público", 2" ed., Rio de Janeiro, Gráfica do IBGE, 1956, vol. II, p. 92.

(12) Veja-se Michel Bélanger, "Droit International de la Santé", Paris, Economica, 1983, pp. 77/78. 
No tema das Organizações Internacionais, dentro do Direito Internacional Público, foi no Tratado de Versalhes de 1919, na sua Parte XIII (arts. 387-426, seção originalmente intitulada "A Organização Permanente do Trabalho", e art. 427, denominado "A Carta do Trabalho"), que emergiu uma entidade intergovernamental permanente, com a denominação moderna $e$ a estrutura organizacional e que se repetiria na maioria das organizações intergovernamentais da atualidade: Organização Internacional do Trabatho. Interessa observar que a outra entidade estabelecida por aquela Paz, como uma organização cimeira que deveria cuidar da manutenção da paz, não se denominava "organização", mas "Sociedade das Nações", SdN (que passaria a ser conhecida, igualmente, como "Liga das Nações"). Relembre-se, ademais, que a Sociedade das Nações teve vida efêmera, enquanto organização que pretendia evitar outra guerra mundial, nos moldes daquela a que o Tratado de Versalhes tinha posto fim: a) consagrava a regra da responsabilidade global de todos os Estados-Membros na manutenção da paz (ao haver adotado, com um ingênuo irrealismo, a regra da unanimidade de suas deliberações), fator que a tornou inoperante, em particular, por tratar-se de um colegiado com inúmeros membros compostos de Estados ainda relutantes, naquele momento histórico, em abdicar de seus poderes soberanos, em favor de uma organização intergovernamental; b) nunca foi verdadeiramente universal, pois em nenhum momento os EUA, Estado já importante nas relações internacionais daquele período, foram membros da Liga das Nações (pela recusa de o Senado Federal norte-americano aprovar o Tratado de Versalhes e impossibilitar sua ratificação por aquele país) e c) em nenhum momento conseguiu colocar frente a frente os grandes adversários políticos do final da guerra e do entreguerras, a URSS e a Alemanha (quando esta foi admitida, a URSS tinha sido expulsa, por sua invasão na Finlândia, e quando a Alemanha, então dominada pelo Nacional Socialismo foi eleita membro permanente do Conselho, o Brasil, em protesto, retirar-se-ia da Liga).

No relativo aos assuntos sanitários internacionais, o final da Grande Guerra viria encontrar uma situação catastrófica na Europa, que tinha sido palco de uma das guerras mais mortíleras empreendidas naquele Continente: o tifo havia dizimado a URSS e a Europa do Leste (200.000 casos de óbitos na Polônia e mais de 1.600 .000 na URSS), os países mediterrâneos enfrentavam um novo surto de cólera e uma grande pandemia de gripe (influenza), em 1918-1919, havia causado a morte de cerca de 15 milhões de pessoas ${ }^{(13)}$. Em que pesasse a importante obra do Escritório Internacional de Higiene Pública, sediado em Paris, não possuía ele os meios financeiros e a competência para enfrentar os desafios quanto aos problemas de saúde pública do período, em particular numa Europa que mal conseguia reestruturar os serviços públicos locais.

(13) Dados apud Antoine H. Zarb, "Les Institutions...", cit., p. 42. 
Por tais motivos, numa Conferência Internacional de Higiene, convocada sob a égide do Conselho da Sociedade das Nações, reunida em Londres, de 13 a 17 de abril de 1920 (onde somente estiveram representados os EUA, França, Grä-Bretanha, Itália e o Japão), recomendou-se à SdN a criação de uma organização internacional permanente de higiene, em cujo seio seria integrado o Escritório Internacional de Higiene Pública. De tais esforços resultaria constituída a Organização Permanente de Higiene da Sociedade das Nações, com sede em Genebra, que, no entanto, não conseguiria englobar o Escritório Internacional de Higiene Pública, com sede em Paris, pela impossibilidade de os EUA participarem da SdN. Portanto, no entreguerras, havia, na Europa, duas organizações internacionais intergovernamentais, que, em princípio, tinham finalidades assimiladas, conquanto houvesse uma participação distinta de Estados numa e noutra (tendo o Brasil participado de ambas); sem embargo de tal duplicidade, as necessidades de cooperação entre ambas as organizações eram patentes, a ponto de a Organização Permanente de Higiene da SdN haver constituido o Escritório de Paris como seu Conselho-Geral Consultivo de Higiene (ao lado de seus dois outros órgãos: um Comitê de Higiene e uma Seção de Higiene do Secretariado da SdN).

Com o evolver de suas atividades, foram instituídas na Organização da SdN, em Genebra, várias Comissões: a Comissão de Epidemias, instituída para tratar de uma nova epidemia que surgira após a Grande Guerra, o tifo, outras Comissões: do paludismo, sobre o câncer, sobre a lepra (na época não era utilizada sua denominação atual: hanseníase), sobre a estandardização biológica, sobre a habitação, sobre o ensino de higiene, sobre a higiene rural e, nos anos imediatos antecessores da Segunda Guerra Mundial, sobre determinadas doenças ditas sociais, em particular aquelas resultantes de falta de nutrição. No que se refere às suas funções de difusão de informações, é importante notar a continuidade da sua publicação técnica, Relevé Épidémiologique Hebdomadaire, que, mesmo após a eclosão da guerra de 1939-45, não sofreria interrupção.

A importância de ambas as entidades sanitárias iuternacionais se revelaria, já nos momentos finais do término da Segunda Guerra Mundial, quando as hostilidades permitiram ações concertadas em termos de cooperação internacional em matéria sanitária, em face da completa desorganização dos serviços sanitários locais ${ }^{(14)}$. Num Acordo firmado em Washington, em 9 de

(14) É interessante observar que, mesmo que a paz ainda não tivesse sido selada em acordos internacionais, os Estados já se colocaram de acordo, com vistas à instituiçāo de organizaçōes internacionais em assuntos tópicos. Assim, em maio de 1943, uma Conferência sobre Alimentação de Agricultura determinaria as bases do que seria a FAO; em novembro de 1943, a instituição da UNRRA; em julho de 1944, a assinatura dos Acordos de Bretton-Woods (instituição do Banco Mundial e do Fundo Monetário Internacional), e, enfim, em dezembro de 1944, a assinatura em Chicago da Convenção sobre Aviação Civil Internacional, que instituiria a OACI, ou ICAO (Organizaçāo da Aviação Civil internacional). Veja-se: $D$. H. Bowett, "The Law of International Institutions", $3^{\natural}$ ed., London, Stevens \& Sons, 1975, p. 53. 
novembro de 1943 , fundava-se uma entidade transitória, a United Nations Relief and Rehabilitation Administration, UNRRA ${ }^{(15)}$, com a finalidade precípua de resolver os graves problemas dos refugiados de guerra e que, a partir de janeiro de 1945, deveria assumir as funções da Organização Permanente de Higiene da SdN no referente à aplicação das convenções sanitárias internacionais. A fim de poder exercer sua missão de luta e prevenção contra epidemias (em especial naqueles tempos de guerra), a UNRRA adotaria as duas Convenções de Washington de 1944 (15 de dezembro), a Convenção Sanitária Internacional (modificadora da Convenção Sanitária de 1926) e a Convenção Internacional Sanitária para a Navegação Aérea (modificadora daquela de 1936), que adicionava outras doenças pestilenciais àquelas moléstias transmissíveis anteriormente contempladas nas normas internacionais, além de modernizar métodos de seu combate e prevenção, em particular à vista da descoberta e utilização generalizada da penicilina e do DDT. Destaque-se que todas as funções epidemiológicas da UNRRA seriam, a $1^{\circ}$ de dezembro de 1946, transferidas à Organizaçăo Mundial da Saúde.

Os antecedentes imediatos da constituição da Organização Mundial da Saúde encontram-se nas discussões dos tratados de paz que colocariam um final na Segunda Guerra Mundial e que instituiriam o sistema da segurança coletiva sob responsabilidade da Organização das Nações Unidas. Assim, foi durante a Conferência de São Francisco, realizada em 1945, nos EUA, quando então se elaborava a Carta da ONU, que, por proposta conjunta das delegações do Brasil e da China, foi aprovada uma Recomendação, em virtude da qual deveria ser convocada uma conferência diplomática mundial, com vistas a estabelecer uma organização mundial da saúde. O resultado imediato da aprovação unânime de tal proposta foi haver feito constar no texto mesmo da Carta da ONU que a organização cimeira então constituída deveria, dentre seus propósitos, favorecer: "a solução dos problemas internacionais econômicos, sociais, sanitários e conexos..." (art. 55, que se encontra no Capítulo IX, "Cooperação Internacional Econômica e Social", que merecerá uma análise mais detalhada, na próxima seção a seguir). Em 16 de fevereiro de 1946, o Conselho Econôınico e Social da ONU, o ECOSOC, por ocasião de sua sessão inaugural, daria efeito à proposta sino-brasileira, tendo decidido pela convocação de uma Conferência Internacional com a finalidade de "estudar a extensão e os mecanismos da ação internacional a serem empreendidos no domínio da saúde pública, bem como de propostas visando à criação de uma organização internacional única das Nações Unidas para a saúde", além de ter constituido uma comissão técnica preparató-

(15) A UNRRA, organização formada por 44 Estados, um dos quais a URSS, funcionaria da data de sua instituição até 3 de junho de 1947, quando seria dissolvida e suas funções e haveres seriam distribuidos por entre a Organização Mundial da Saúde, a Organização das Nações Unidas para a Alimentaçāo (FAO, com sede em Roma) e para o Fundo das Naçōes Unidas para a Infância (UNICEF). Veja-se Michel Bélanger, "Droit International...", cit., pp. 21/22. 
ria que deveria preparar a ordem do dia daquela conferência internacional e um projeto de constituição da futura organização internacional(16). Uma Conferência Internacional da Saúde se reuniria em Nova York, na sede da ONU, em 19 de junho de 1946, ao final da qual seria assinada, a 22 de julho daquele ano, a Constituição da Organização Mundial da Saúde. A Constituição da OMS entraria em vigor a 7 de abril de 1948 (data do depósito por 26 Estados signatários, igualmente membros da ONU, da aceitação daquele tratado internacional), tendo aquela organização sido sediada em Genebra, tendo igualmente herdado os direitos e deveres do Escritório Internacional de Higiene Pública, da Organização de Higiene da SdN e da UNRRA, e tendo estabelecido estreitas e institucionais vinculações com o então Escritório Panamericano de Saúde, realizaria sua Primeira Assembléia Mundial da Saúde em 24 de junho de 1948.

Uma breve e notável descrição da OMS é fomecida pelo Prof. Antoine $H$. Zarb da Universidade de Nice e antigo Conselheiro Jurídico e Diretor do Serviço Jurídico daquela organização, redigida nos seguintes termos: "A Constituição da Organização Mundial da Saúde, ao consagrar o alargamento do conceito de 'saúde', determinava aos signatários considerarem a saúde como 'um estado de completo bem-estar físico, mental e social', consistente não unicamente 'na ausência de saúde ou de enfermidade"' (17), e lembrava que "a saúde de todos os povos é a condição fundamental da paz do mundo e da segurança", e que ela dependia "da mais estreita cooperação dos indivíduos e dos Estados" 18$)$.

Deve-se notar que, com a constituição da OMS, ou com o simples exame de sua atuação, não se esgotam as complexidades do Direito Internacional Sanitário. Conforme já apontamos, as relações internacionais do século XX têm sido caracterizadas pela transcendental importância da diplomacia multilateral, ou, em outras palavras, pela proliferação de entidades internacionais, que se constituem não somente em foros de negociações entre Estados, mas sobretudo em fontes de normas internacionais, dos mais variados tipos de força normativa. Neste particular do ponto de vista meramente descritivo, poderíamos referir-nos a dois grandes tipos de organizações internacionais, as Ols, organizações intergovernamentais, e as ONGs, organizações não governamentais (igualmente conhecidas pela sigla de sua denominação em inglês: NGOs).

Quanto às organizações internacionais intergovernamentais, são elas constituídas, em geral, por um acordo internacional firmado entre Estados, com órgãos compostos por delegados dos Estados, e com uma personalidade de Direito Internácional, portanto, com sede num Estado determinado, com poderes de receber representantes diplomáticos e enviar os seus tanto

(16) Veja-se Antoine H. Zarb, "Les Institutions..." cit., p. 49.

(17) Nota de rodape original da citação: "Preâmbulo da Constituição da OMS".

(18) "Les Institutions..." cit., p. 49. 
a Estados quanto a outras organizações intergovernamentais e, enfim, com poderes de expedir atos normativos internacionais, com uma tipologia variada de força normativa nas relações interestatais e nas ordens jurídicas internas dos Estados. No campo do Direito Internacional Sanitário, podemos classificar os seguintes subtipos:

a) aquelas entidades inseridas numa ordem sanitária internacional, instituida dentro do sistema das Nações Unidas, que compreenderia 0 estudo não só da atuação da OMS e de todas as entidades internacionais globais ou regionais especificamente ligadas a assuntos de saúde pública, como também das relações entre a OMS e outras organizações internacionais que compõem o sistema da ONU (neste particular, os temas comuns tratados pela OMS, de um lado, e, de outro, os órgãos ad hoc instituídos pela Assembléia Geral da ONU, nos vários campos de refugiados, desarmamento, luta contra a prostituição internacional, o combate internacional às drogas, ou, ainda, as organizações internacionais institucionalizadas, como a FAO (elaboração do Codex Alimentarius), UNESCO, OIT, a Agência Internacional de Energia Atômica etc.); e

b) uma ordem sanitária instituída, paralelamente, seja nas tradicionais organizaçōes intergovernamentais do tipo OEA, Conselho da Europa, Organização da Unidade Africana (OUA), Organização Econômica de Cooperação e Desenvolvimento (OCDE), seja nas modernas organizações intergovernamentais de integração econômica regional, do tipo Comunidade Européia, MERCOSUL, NAFTA, Pacto Andino, ASEAN etc.

No relativo às organizações internacionais não governamentais, as ONGs, trata-se de entidades constituidas segundo o direito interno de um Estado, sem personalidade jurídica de Direito Internacional, mas cuja autoridade científica ou prestígio internacional, pela eficiência de sua ação, e ainda pelos meios financeiros de grande envergadura que possuem (em grande parte, financiadas por poderosos grupos privados empresariais, algumas representativas de poderosos interesses econômicos privados), ou ainda pela força de convencimento de que desfrutam junto à opinião pública internacional, ganham extraordinária relevância nos assuntos da proteção internacional da saúde pública. Constituem-se as ONGs seja como entidades benemerentes e humanitárias, tais como os Médecins sans Frontières, seja como associaçōes científicas (como a Société Internationale de Radiologie, com sede em Paris), seja ainda como representativas de poderosos interesses econômicos privados (tais como, por exemplo, as várias associações internacionais de fabricantes de medicamentos), as ONGs, na área do Direito Sanitário Internacional, representam novos e relevantes atores, ao lado das numerosas organizações intergovernamentais, que devem ser consideradas ao lado do sistema das Nações Unidas, capitaneado pela OMS. O estudo sistemático das ONGs no Direito Internacional ainda está para ser feito, mas, em matéria de Direito Sanitário Internacional, veja-se: Yves Beigbeder, "Le 
Rôle International des Organisations Non Gouvernementales", Paris, Bruxelas, Bruylant/LGDJ, 1992.

\section{VALORIZAÇÃO RENOVADA DOS CONTEÚDOS E FINALIDADES DAS NORMAS INTERNACIONAIS NO SÉCULO XX: A COOPERAÇÃO INTERNACIONAL, A INTERNACIONALIZAÇÃO DOS DIREITOS HUMANOS E O DIREITO À SAÚDE}

O século XX, conforme já deixamos dito anteriormente, tem uma característica inconfundivel em comparação com os séculos anteriores no que respeita às relações internacionais e, conseqüentemente, às normas que as regem, o Direito Internacional: a prevalência dos contatos multilaterais entre os Estados, levados a cabo no seio de organizações internacionais universais, regionais ou bilaterais. Se tais relacionamentos eram esporádicos em séculos anteriores tornam-se institucionalizados e banais no século XX (trata-se da denominada "diplomacia parlamentar", que se exerce, à maneira dos Parlamentos nacionais, de maneira institucionalizada, no seio das organizações intergovernamentais), em parte devido às facilidades dos transportes e das telecomunicações internacionais, em parte devido ao fenômeno da globalização que tem tornado as fronteiras interestatais elementos superados, num ambiente onde o mercado é mundial e único e onde, de igual for$\mathrm{ma}$, as forças da destruição transitam sobranceiras por sobre os poderes regulatórios dos Estados ou os espaços ou elementos dignos da proteção são transfronteiriços. Tais fenômenos, insistimos, são causados seja devido à maior freqüência do movimento internacional de pessoas e bens, seja porque há fenômenos que desconhecem fronteiras físicas entre Estados, como os hábitats protegidos internacionalmente, inclusive as cidades integrantes do Patrimônio Cultural da Humanidade e as obras de arte, seja porque as poluições atmosféricas, marítimas, fluviais e de lençóis freáticos não respeitam limites políticos entre os Estados, tornando indissociável a necessidade de uma regulamentação internacional de seus efeitos, às necessidades de cooperação internacional.

Quanto mais se encaminha para o século XXI, mais e mais entidades internacionais são estabelecidas, para todos os assuntos versados no Direito Internacional. Algumas dessas entidades possuem plena personalidade de Direito Internacional (expressamente assim reconhecidas pelos atos instituidores ou pelas normas consuetudinárias do Direito Internacional), atributo esse que é, genericamente, definido pelos poderes de enviar representantes a Estados ou outras organizações internacionais, com um orçamento próprio, alimentado pelos Estados-Partes ( $\theta$, portanto, um funcionalismo próprio), e os direitos de poder firmar acordos internacionais com Estados ou outras organizações intergovernamentais com poderes semelhantes, inclusive acordos de sede, com os Estados, onde se definem as prerrogativas e imunidades do pessoal a seu serviço, dos agentes diplomáticos acreditados perante tais organizações e dos seus serviços e arquivos oficiais. Há, ainda, outras entidades, autênticas organizações in- 
ternacionais, que, embora previstas em tratados ou convenções multilaterais, não possuem aqueles os atributos típicos da plena personalidade, bastando citar-se como exemplo os órgãos de aplicação e complementação de importantes convenções internacionais, que, ao lado dos Secretariados permanentes sediados em alguma cidade, têm uma relativa presença temporal nas relações intemacionais (por exemplo, a Convenção Quadro das Nações Unidas sobre o Clima ${ }^{(19)}$, que se encontra "sediada" em Bonn, na Alemanha, nem tanto porque o Secretariado daquela Convenção se encontra naquela antiga Capital, mas igualmente porque as reuniões intermitentes do seu órgão supremo, a Conferência das Partes, já encontram suas reuniões agendadas para aquela cidade, bem como os órgãos permanentes técnicos daquela Convenção aí se encontram sediados, conquanto seja o pessoal a serviço da mesma empregado da ONU, através do órgão ambiental desta, o Programa das Nações Unidas para o Meio Ambiente, por sua vez sediado em Nairobi(20)).

O fato é que o próprio Direito Internacional remete a nova orientação que se agregou nas relações internacionais do século $X X$ : a dimensão da cooperação. Se, em séculos anteriores, a cooperação poderia ser considerada como um corolário das boas relações entre os Estados, ou, ainda, como um transbordamento de virtudes de auxiliar os Estados mais necessitados (atitude que poderia, em determinados casos, esconder, sob a máscara de ajuda, auxílio ou "cooperação", uma política de dominação colonial ou neocolonial), o século XX veio dar novos conteúdos a ela, definindo-se a cooperação como um dever nascido da necessidade de regular conjuntamente o ambiente das relações internacionais, sob pena de uma série de providências unilaterais sem eficácia na realidade dos fatos. Se em determinados campos tais fenômenos não aparecem com clareza (em particular nas relações econômicas e comerciais), em outros, em particular no campo da saúde pública internacional e da proteção internacional do meio ambiente, a cooperação se torna uma necessidade inarredável; em outros campos, em especial naqueles de uma consciência ética de valores globais que merecem ser preservados, como a proteção internacional da pessoa humana, a cooperação tem sido "construída" através de mandamentos expressos das normas internacionais, conquanto os valores humanos sejam tidos, intrinsecamente, como universais, mas nem sempre sejam assim reconhecidos pelos Estados, nos respectivos ordenamentos jurídicos internos.

(19) Uma convenção ou tratado "quadro" é o um tipo moderno de ato internacional multilateral, onde se traçam os grandes principios normativos sobre um tema particular, nos quais, portanto, os Estados-Partes criam um espaço normativo (a melhor tradução no vernáculo de sua denominação, em inglês framework, em francês cadre $\theta$ em espanhol marco, teria sido "moldura"), que deverá receber um detalhamento por órgāos instituidos por aqueles atos, em particular as Conferéncias das Partes, em reuniões ordlnárias ou extraordinárias posteriores, as quais năo podem, contudo. inovar além daquele espaço normativo (ou seja, devem pintar um quadro detalhado, dentro da temática definida pela moldura preestabelecida).

(20) Por outro lado, não deixa de ser curioso o fato de o PNUMA. bem como o Programa das Nações Unidas para o Desenvolvimento, PNUD, outra fonte de financiamento de atividades internacionais, terem personalidade jurídica de Direito Internacional, não sendo tais programas da Assembléia Geral da ONU organizaçర̃es internacionais clássicas! 
O fato é que a cooperação, como um elemento fundamental das relações internacionais da atualidade, explica, inclusive, como jă apontamos, a mudança de enfoque do próprio Direito Internacional: de um conjunto de regras de fundo proibitivo (na verdade, apoiadas na idéia de entidades todopoderosas, apenas limitadas pelas normas proibitivas do Direito Internacional, que fora formado por concessões unilaterais de cada Estado), substituise pela idéia de um conjunto de regras mandamentais de não apenas manter a paz e o status quo, mas, igualmente, de adotar comportamentos específicos a fim de realizar um mando mais equânime, ou, pelo menos, menos desequilibrado em temos de benefícios.

Tais fatos explicam por que no Direito Internacional dos séculos anteriores o tema da cooperação entre Estados era apenas aflorado na doutrina filosófica dos autores, por que não havia maior previsão sobre ele nos grandes atos normativos (salvo como mera retórica nos grandes tratados de paz), ainda por que, no Pacto da Sociedade das Nações, se encontra sem expressão e, enfim, porque na Carta de São Francisco ganhou um inteiro capítulo, com dispositivos precisos, além de terem os Estados fundadores da ONU a ela reservado um órgão particular: o Conselho Econômico e Social, o ECOSOC.

Com efeito, conforme assinalou o Prof. Edward McWhinney (21), "o tema da cooperação ${ }^{(22)}$ somente aparece na linguagem do Direito Internacional, após a Segunda Guerra Mundial. É empregado, primeiramente, para afirmar o direito que os Estados têm no Direito Internacional de cooperar uns com os outros, conforme a Carta das Nações Unidas, mas, igualmente, numa acepção mais ampla, de caráter genérico, para designar um domínio particular do Direito Internacional" (p. 445). Na verdade, o primeiro texto normativo internacional que, de maneira direta, se refere a "cooperação", muito significativamente, aparece expresso, na Carta das Naçōes Unidas, portanto, junto com a instituição da mais importante organização internacional do Pós-Guerra: trata-se do art. $1^{\circ}, \S 3^{\circ}$, consistente na enunciação das finalidades da ONU ("realizar a cooperação internacional, resolvendo os problemas internacionais de ordem económica, social, intelectual ou humanitária, desenvolvendo e encorajando o respeito dos direitos do homem e das liberdades fundamentais para todos, sem distinção de raça, sexo, de língua ou religiāo"), e mais claramente disciplinado nos arts. 55 e 56, inscritos no Capitulo IX daquele diploma, cognominado "Cooperação Internacional Econômica e Social"(23), verbis:

(21) "Le Concept de Coopération", apud Mohammed Bedjaoui, redator-geral, "Droit International, Bilan et Perspectives", Paris, Editions A. Pedonne, UNESCO, 1991, tomo 1, pp. 445/458.

(22) Seguiremos, nas citaçōes da doutrina, os textos tal qual publicados, com ou sem a adjetivação do termo "cooperação", segundo conste ou não dos originais.

(23) Atente-se para o fato de que a ONU, contrariamente à sua antecessora, a Liga das Naçōes, além do trato de questōes políticas que interessam diretamente à manutençāo da paz, inaugurou a temática das questões econômicas e sociais como uma de suas principais atribuiçōes, enquanto organização cimeira das relaçōes internacionais entre os Estados. Tais atribuiçōes se encontram concentradas no Conselho Econômico e Social, o ECOSOC, um dos cinco órgãos da ONU, que como se sabe, são: a Assembléia Geral, o Conselho de Segurança, o Conselho de Tutela e a Corte Internacional de Justiça, todos sediados em Nova York, com exceção da Corte, sediada na Haia. 


\section{Artigo 55}

Com o fim de criar condições de estabilidade e bem-estar, necessárias às relações pacíficas e amistosas entre as Nações, baseadas no respeito ao princípio da igualdade de direitos e da autodeterminação dos povos, as Nações Unidas favorecerão:

a) niveis mais altos de vida, trabalho efetivo e condições de progresso e desenvolvimento econômico e social;

b) a solução de problemas internacionais econômicos, sociais, sanitários e conexos; a cooperação internacional, de caráter cultural e educacional; e

c) o respeito universal e efetivo dos direitos humanos e das liberdades fundamentais para todos, sem distinção de raça, sexo, língua ou religião.

\section{Artigo 56}

Para a realização dos propósitos enumerados no art. 55 , todos os Membros da Organização se comprometem a agir em cooperação com esta, em conjunto ou separadamente.

Tais deveres de cooperação definidos na Carta da ONU seriam, na data dos 25 anos de comemoração da existência daquela organização cimeira da atualidade, reafirmados com a Declaração da AG das Nações Unidas relativa aos Princípios de Direito Internacional no tocante às Relações Amigáveis e à Cooperação entre os Estados, adotada pela Resolução n. 2.625 (XXV) de 24 de outubro de 1970.

Reportando-se à existência de um "novo Direito Internacional da Cooperação, ainda incompleto, uma categoria jurídica em vias de formação", mostra aquele Professor canadense que o mesmo se formou a partir de transformaçōes de conceitos do antigo Direito Internacional (como o abuso de direito), com a permeação dos conceitos de justiça e eqüidade nas relações internacionais e através da elaboração de conceitos novos, como o direito de vizinhança, e teve sua consagração escrita na citada Declaração da $A G$ da ONU. Nas suas palavras: "a aplicação do Direito Internacional da cooperação, em casos concretos, faz intervir a noção de relatividade dos direitos e supõe que sejam colocados em equilíbrio as vantagens que podem ter as ações de um Estado e o dano que delas pode resultar para outros Estados" (ob. cit., p. 457).

Um relevante estudo coletivo produzido no Brasil, onde se mostram as importantes e renovadas vertentes da cooperação internacional, conquanto não tenha versado especificamente sobre questões do Direito Sanitário Internacional, é a obra publicada em São Paulo, em 1994, pela Editora da Universidade de São Paulo, sob a direção do então Prof. Dr. Jacques Marco- 
$v^{\text {vitch }}{ }^{(24)}$, "Cooperação Internacional: Estratégia e Gestão", da qual participamos, com um trabalho intitulado: A Cooperação Técnica Internacional, pp. $165 / 218$.

Além desta nova vertente voltada à cooperação que todo o Direito Internacional ganharia com o sistema das Nações Unidas, e que já de per si constitui um dos fundamentos típicos do Direito Internacional Sanitário, este ganharia novas formulações normativas, no sentido de reforçar sua importância e sua eficácia. Referimo-nos ao fato de haver o direito à saúde sido definido como um dos direitos fundamentais da pessoa humana, garantidos pelo Direito Internacional positivo. Tal fato propiciaria que, com tais roupagens, o Direito Sanitário Internacional passasse a beneficiar-se de todo o arsenal jurídico que foi construído para a efetivação das normas protetoras dos direitos humanos, inclusive com o acesso direto de indivíduos, a tribunais internacionais especialmente criados no âmbito dos Direitos Internacionais da Pessoa Humana.

Conforme mostramos no artigo "O Meio Ambiente e a Justiça no Mundo Globalizado", estampado na publicação do Centro de Extensão Universitária de São Paulo, Justiça Penal, Críticas e Sugestões, 10 Anos da Constituição e a Justiça Penal (São Paulo, Revista dos Tribunais, 1999, pp. 65/ 118), com apoio nas teses dos Profs. Norberto Bobbio e Celso Lafer, a proteção dos direitos humanos passou por um expressivo processo histórico, que principiou com a conscientização daqueles valores transcendentais. Pela obra doutrinária produzida através dos tempos, recebeu, a seguir, uma valorização normativa nos sistemas jurídicos internos dos Estados (com o movimento generalizado da introdução dos mesmos nas normas constitucionais), para, no século XX, ganhar foros internacionais, com vistas à sua mais efetiva positivação, através:

a) de seu arrolamento em significativos atos nomativos internacionais, de consagração solene destes (a Declaração Universal dos Direito do Homem, proclamada pela Assembléia Geral da ONU em 10 de dezembro de 1948 e as declarações regionais que se seguiram);

b) de na sua formalização como direitos e deveres expressamente constantes em tratados e convenções internacionais, seja os de natureza geral (os Pactos Internacionais, sobre Direitos Econômicos, Sociais e Culturais e o sobre Direitos Civis e Políticos, adotados pela AG da ONU a 16 de dezembro de 1966, que foram incorporados no ordenamento jurídico brasileiro pelo Decreto n. 592, de 6 de dezembro de 1992, que os promulgou), seja os de natureza tópica (por exemplo: a Convenção para a Prevenção e a Repressão do Crime de Genocídio de 1948, no Brasil promulgada pelo Decreto n. 30.822, de 6 de maio de 1952);

(24) Em 1999, quando da redação do presente trabalho, o Prof. Jacques Marcovitch era o M. Reitor da USP. 
c) da instituição de mecanismos internacionais de verificação efetiva da adimplência, pelos Estados, daqueles direitos, seja em nível global (instituição da Comissão de Direitos Humanos pela ONU, com sede em Genebra, e seus mecanismos de investigação e conscientização internacional das violações por parte de indivíduos e das autoridades internas dos Estados), seja em nível regional (com a subscrição dos tratados regionais de proteção aos direitos humanos, a instituição de mecanismos diplomáticos regionais, na Europa, na América e na África);

d) do aperfeiçoamento, em nível regional, dos mecanismos de controles e verificação da efetiva aplicação daqueles direitos pelos Estados, com a criação de tribunais independentes regionais, a Corte Européia dos Direitos Humanos, com sede em Estrasburgo, e a Corte Americana dos Direitos Humanos, com sede em San José, na Costa Rica, sendo que, no caso europeu, já se admite o acesso direto da pessoa humana aos procedimentos judiciários, inclusive aqueles intentados contra o Estado de sua nacionalidade ou residência;

e) enfim, a constituição, por um tratado internacional firmado em 1998, em Roma, por iniciativa da Comissão dos Direitos Humanos da ONU, de um Tribunal Penal Internacional, com uma definição precisa da tipologia dos crimes e delitos internacionais, a jurisdição do tribunal, a competência dos juízes internacionais, bem como o estabelecimento dos procedimentos perante aquela Corte.

Ora, o fato de o direito à saúde ter sido integrado no rol dos direitos humanos, desde a primeira definição destes em nivel internacional na Declaração Universal dos Direitos do Homem de 1948, com repetição nos Pactos de 1966, bem como uma reiteração nos grandes instrumentos internacionais regionais, tem por conseqüência atribuir ao Direito Internacional Sanitário quaisquer mecanismos inerentes à proteção dos direitos humanos, seja no campo diplomático (as ações nas Comissões da ONU e nas regionais instituídas por tratados específicos), seja, ainda, no campo da competência jurisdicional dos tribunais regionais e, agora, no Tribunal de Roma.

$\mathrm{Na}$ atualidade, não mais existem dúvidas quanto às interligações essenciais entre o Direito Intemacional Sanitário e o Direito Internacional da Pessoa Humana. Vejam-se, sobretudo, os estudos propiciados em 1978, num colóquio realizado na Haia, organizado pela Academia de Direito Internacional da Haia e pela Universidade das Nações Unidas, do qual resultaria uma importante obra, significativamente denominada "O Direito à Saúde enquanto Direito do Homem" (Académie de Droit International de la Haye et Université des Nations Unies, Colloque 1978 (27-29 juillet 1978), Le Droit à la Santé en tant que Droit de l'Homme, Alphen aan den Rijn, Sijthoff \& Noordhoff, 1979). Entre nós, veja-se a Dissertação de Mestrado da Profa. Dra. Valéria 
Simões Lira da Fonseca: "O Direito Internacional face à Saúde e às Moléstias Transmissíveis", defendida, em 27 de junho de 1990, na Faculdade de Direito da USP, bem como a relevante contribuição do Prof. Dr. Antonio Augusto Cançado Trindade, na área da proteção internacional dos direitos humanos, no capítulo do direito à saúde (em especial seu estudo "Meio Ambiente e Desenvolvimento: Formulação e Implementação do Direito ao Desenvolvimento como um Direito Humano", in Boletim da Sociedade Brasileira de "Direito Internacional", ano XLV, jul./nov. de 1992, n. 81/83, pp. 49/76).

\section{A ORGANIZAÇÃO MUNDIAL DA SAÚDE E SUA PRINCIPAL TAREFA NORMATIVA}

Como já dito, a OMS foi instituída por uma convenção internacional assinada em Nova York, a 22 de julho de 1946, quando então se adotaria a Constituição da Organização Mundial da Saúde. Nascida a partir de iniciativa da própria ONU (relembrando-se, por proposta sino-brasileira aprovada na primeira reunião do ECOSOC e que daria causa aos trabalhos preparatórios empreendidos em Paris e à convocatória da conferência, na sede da $\mathrm{ONU}$ ), logo se transformaria numa das agências especializadas das Nações Unidas $^{(25)}$, com as prerrogativas que estas possuem (e que, portanto, não devem ser confundidas com os órgãos ordinários ou especiais da ONU, nem com seus órgãos subsidiários). Conforme as normas constantes da Carta da ONU, as agências especializadas são autênticas organizaçōes internacionais, instituídas por tratados multilaterais (tratados-fundação), com membros não necessariamente idênticos aos membros da ONU (observe-se, ademais, que, enquanto na ONU somente se admitem Estados independentes, na OMS se admitem, na qualidade de membros ordinários, somente Estados independentes, e, como membros associados, territórios ou grupos de territórios que não tenham a responsabilidade pela condução das respectivas relações intemacionais ${ }^{(26)}$ ); embora com uma personalidade jurídica própria, as agências especializadas, conquanto tenham um orçamento próprio, votado pelas respectivas Assembléias Gerais, encontram-se relativamente submetidas à ONU (através da coordenação do ECOSOC), uma vez que seus orçamentos podem ser examinados pela Assembléia Geral da ONU,

(25) "Agências especializadas da ONU" é a denominação constante na tradução brasileira da Carta d:a ONU. Outras denominações para o mesmo fenómeno, igualmente correntes, sāo: "organizações especializadas da ONU", mais encontradiças na doutrina e mesmo constantes em diplomas oficiais internacionais, ou, ainda, "organizaçōes internacionais do sistema da ONU", mais usada na doutrina. Não se confundem com as entidades criadas pela Assembléia Geral da ONU como seus órgāos subsidiários, tais como a Comissão de Direitos Humanos, a Comissão de Desarmamento, a UNCTAD (Comissảo das Nações Unidas para o Comércio e o Desenvolvimento), que são meros apêndices daquela Assembléia, instituídos com a finalidade de desconcentrar serviços e funções.

(26) Situação que se verificou, por exemplo, com a antiga Rodésia, antes de sua independência e a constituição de um novo Estado, o Zimbabwe. 
com a possibilidade de esta redigir àquelas recomendações em matéria orçamentária (art. 17, $\S 3^{\mathbf{9}}$, da Carta da ONU). Por outro lado, o status de agência especializada permite ao Conselho de Segurança da ONU e a seu Conselho de Tutela recorrer aos serviços das mesmas, dentro das áreas das respectivas competências. Deve-se enfatizar outra característica das agências especializadas: como os Estados, têm acesso à Corte Internacional da Justiça, conquanto devam, para tanto, ser autorizadas pela AG da ONU (id., art. $96, \S 2^{\circ}$ ), mas somente em matéria não contenciosa, ou seja, unicamente para pedir-the pareceres consultivos (excluida, portanto, a possibilidade de a Corte Internacional de Justiça ser chamada para dirimir conflitos, no exercício de sua jurisdição contenciosa, seja entre uma agência especializada e um Estado, ou entre uma agência especializada e outra agência especializada ou entre esta e outra pessoa de Direito internacional). Outro fato importante quanto a ser uma organização internacional intergovernamental uma agência especializada da ONU reside na possibilidade de poder ela firmar "acordos de sede", ou seja, convênios internacionais entre ela e o Estado que a sedia (na verdade, são poucas as cidades que sediam agências especializadas da ONU: Berna ${ }^{(27)}$, Genebra ${ }^{(28)}$, Londres ${ }^{(29)}$, Montreal(30), Paris $^{(31)}$, Roma ${ }^{(32)}$, Viena ${ }^{(33)}$ e Washington ${ }^{(34)}$, nos quais se reconhecem privilégios e imunidades à organização, a seus arquivos e serviços, a seu pessoal administrativo permanente e a delegados dos Estados Membros da organização enviados a suas reuniōes ordinárias ou extraordinárias). As pessoas a serviço das agências especializadas, quando em missões em qualquer Estado ou território, têm imunidades e privilégios perante as autoridades internas dos Estados ou territórios onde exercem suas funções ordinárias ou

(27) Uniāo Postal Universal, UPU.

(28) Organização Mundial da Saúde, OMS (ou WHO), Organizaçăo Internacional do Trabalho, OIT (ou ILO). Uniâo Internacional das Telecomunicaçôes, UIT (ou ITU), Organização Mundial da Propriedade Intelectual, OMPI (ou WIPO), Organização Meteorológica Mundial, OMM (ou WMO), Organização Mundial do Comércio, OMC (ou WTO), esta última sucessora do antigo GATT (General Agreement on Tariffs and Trades).

(29) Organização Marítima Internacional (OMI, ou IMO), antiga Organização Marítima Consultiva Intergovernamental, OMCl (ou IMCO).

(30) Organizaçảo da Aviaçăo Civil Internacional, OACI (ou ICAO).

(31) Organização das Naçōes Unidas para a Educação, Ciência e Cultura, UNESCO (sigla a partir de sua denominação em inglês: United Nations Education, Science and Culture Organization).

(32) Organização para a Alimentação e Agricultura, FAO (sigla para Food and Agriculture Organization) e, provisoriamente, o Fundo Internacional de Desenvolvimento Agricola, FIDA (ou IFAD).

(33) Agència Internacional de Energia Atômica, AIEA (ou IAEA) e Organização das Nações Unidas para o Desenvolvimento industrial, ONUDI (ou UNIDO).

(34) As instituiçōes denominadas "Bretton-Woods", ou seja, o Fundo Monetário Internacional, FMI (ou IMF), e o assim chamado "Grupo do Banco Mundial"; o próprio Banco Mundial (na verdade, sua denominação oficial é Banco Internacional de Reconstrução e Desenvolvimento, BIRD, ou, em inglês: IBRD), a Agência Internacional de Desenvolvimento, AID (ou IDA), a Corporação Financeira Intemacional, CFI (ou IFC), também conhecida como Sociedade Financeira Internacional (SFI), o Centro Internacional para as Resoluções de Disputas sobre Investimentos Internacionais, CIRDI (ou ICSID) e a Agéncia Internacional para a Garantia de Investimentos, MIGA (sigla a partir de sua denominaçāo em inglês: Multilateral Investments Guarantee Agency). 
extraordinárias, seja em virtude de acordos especiais entre aquelas organizações internacionais e os Estados receptores, seja por força de normas votadas pelas próprias organizações internacionais; tais privilégios e imunidades destinam-se a proteger as pessoas a serviço oficial, os documentos produzidos e os meios de telecomunicações utilizados por elas, em particular naquelas situações constrangedoras de verificação de adimplência de obrigaçōes internacionais, por exemplo, quando se trata de inspetores internacionais, que devem ter acesso a lugares ou pessoas, em geral vedados ao público (casos de desarmamento, verificação do tratamento de pessoas quanto ao respeito aos direitos humanos e, sobretudo, na verificação, por funcionários internacionais, do estado de higidez e sanidade de lugares e/ou da existência e eficácia de serviços públicos ou privados obrigatórios, segundo as normas internacionais).

A OMS tem uma estrutura tripartite, comum à maioria das organizações internacionais da atualidade, com uma particularidade, a seguir mencionada:

a) uma Assembléia Geral (na OMS denominada Assembléia Mundial da Saúde), órgão supremo e deliberativo, composto por delegados de todos os membros da organização (na qual os membros associados não dispōem de poder de voto), e que se reúne uma vez ao ano (na OMS em geral em maio), e na qual se admitem observadores, ou seja, representantes de outras organizaçōes intergovernamentais e de ONGs (representações essas sem direito a voz e voto);

b) um Conselho, órgão deliberativo, composto, na atualidade, após várias emendas à Constituição da OMS, de 31 membros, delegados dos Estados eleitos pela Assembléia, órgão executivo que se reúne permanentemente em Genebra, na sede da OMS;

c) um Secretariado, composto de um funcionalismo de natureza administrativa e de natureza técnica, integrado por pessoas que, em principio, devem guardar neutralidade em relação aos respectivos Estados de sua origem (nacionalidade ou residência), chefiado por um Diretor Geral, indicado pela Assembléia Geral, para um mandato de 4 anos, renováveis ${ }^{(35)}$.

A particularidade da OMS em relação a outras agências especializadas da ONU reside no fato de sua Constituição, nos arts. 44 e 45, ter expressamente previsto ser ela uma organização com estrutura descentralizada, ou, melhor dito, regionalizada, ou seja, com órgãos regionais, localizados em várias partes do mundo (na verdade, este se encontra dividido em 6

(35) Um dos Diretores-Gerais da OMS, no periodo de 1953 a 1973, foi o Dr. Marcolino Candau, médico brasileiro. 
regiões $\left.{ }^{(36)}\right)$. Tal fenômeno deriva de já haver a OMS, por ocasião de sua instituição, encontrado algumas organizações regionais, com suficiente experiência e com uma personalidade internacional bem definida, nomeadamente a Organização Panamericana de Saúde, como já dissemos, a pioneira das organizações internacionais; por outro lado, é mister considerar as necessidades de uma descentralização da regulamentação internacional dos serviços sanitários internacionais, que, na sua essência, devem refletir as necessidades e as realidades regionais. Cada região do mundo possui um Comitê regional, com a representação de todos os Estados ou territórios da região, e um Escritório Regional, chefiado por um Diretor Regional, designado pelo Comitê regional, aprovado e nomeado pelo Conselho da OMS. No caso das Américas, o Comitê regional é a própria OPS, com sede em Washington.

Ainda na sua caracteristica de descentralização regional, a OMS pode credenciar entidades, em geral públicas, como Centros de Referência da OMS, que passam a contribuir com ela na tarefa de elaborar, aperfeiçoar e manter, com padrões da mais alta qualidade técnica, as normas sobre vários assuntos de saúde pública, tais como os aspectos clínicos, estudos científicos e ensino de práticas médicas das mais variadas doenças humanas e animais, como o Centro Internacional de Pesquisa sobre o Câncer, instituído pela própria OMS, em 1965, com sede em Lyon, ou o Centro Internacional da OMS para o Paludismo, em Bethesda, EUA. Dos Centros de Referência, destaquem-se os Centros para a Classificação das Doenças, em língua francesa (Paris), inglesa (Londres), russa (Moscou) e espanhola (Caracas); na atualidade, acha-se em processo preliminar de credenciamento, como centro de classificação de doenças em língua portuguesa, o Centro de Estudos e Pesquisas em Direito Sanitário de São Paulo - CEPEDISA, entidade sediada na Faculdade de Saúde Pública da USP, que, de nosso conhecimento, no mundo, é a única entidade em funcionamento especialmente dedicada a estudos de Direito Sanitário (devendo-se dizer que existe outra, junto à Universidade de Harvard, nos EUA, atualmente desativada) ${ }^{(37)}$.

As competências da OMS, que se encontram elencadas no art. $2^{\circ}$, que constitui o Capítulo II de sua Constituição, ementado como "Funções", de maneira geral podem ser descritas como: propiciar a cooperação entre os Estados, no seu mais amplo espectro (assistência na organização dos serviços administrativos e técnicos locais, difusão de informações, propiciamento de estudos técnicos e formação de pessoal técnico e científico, assistên-

(36) São as seguintes: região européia (Copenhagen), região africana (Brazaville), regiăo das Américas (confundida com a OPS, portanto, sede em Washington), regiäo do Mediterrâneo oriental (Alexandria), região do Sudeste asiático (Nova Delhi) e regiảo do Pacífico ocidental (Manilha).

(37) Os dados sobre o CEPEDISA e o centro desativado existente em Harvard nos foram cedidos pela Profa. Dra. Sueli Gandolfi Dallari, fundadora e Diretora daquele Centro no Brasil. Para informações sobre os Centros de Referência, veja-se, do Prof. Michel Bélanger, "Droit International..." cit., pp. 74 e ss. 
cia em casos de emergências, etc.) e propiciar a formação de um Direito Internacional Sanitário, ou seja, exercer atividades normativas em nível mundial. As atividades normativas, cuja descrição se encontra em algumas alíneas do mencionado art. $2^{9}$, constituem o que hoje, na atualidade do Direito Internacional, se insere no fenômeno da harmonização legislativa internacional, tendo em vista os sistemas jurídicos internos dos Estados:

- propor convenções, acordos e regulamentos, fazer recomendações concernentes às questöes internacionais de saúde e executar os encargos que possam ser afetos por tais atos à Organização, e que correspondem aos seus objetivos (alínea $k$ );

- estudar e difundir, em cooperação, se necessário, com outras instituições especializadas, normas administrativas e sociais relativas à saúde pública e à assistência médica preventiva e curativa, inclusive de serviços hospitalares e de segurança social (alínea p);

- organizar e rever, de acordo com as necessidades, a nomenclatura internacional de doenças, das causas de morte e dos métodos de higiene pública (alínea s);

- padronizar, conforme for conveniente, os métodos de diagnóstico (alínea t);

- desenvolver, estabelecer e estimular ạ adoção de normas internacionais, no que se refere à fabricação de produtos alimentícios, biológicos, farmacêuticos e similares (alínea $u$ ).

Segundo sua Constituição, a OMS tem competência para expedir três tipos de atos:

a) convenções e acordos (previstos nos arts. 19 e 20) são atos adotados pela Assembléia Mundial da Saúde, com o quorum de maioria de $2 / 3$ de votos favoráveis. Necessário dizer que a competência normativa da OMS de propor acordos e convenções internacionais em matéria sanitária internacional não tem sido colocada em prática. Os acordos e convenções internacionais ${ }^{(38)}$, entendidos como atos internacionais solenes entre Estados, em geral são negociados em conferências diplomáticas ad hoc ${ }^{(39)}$, seja convocadas por Estados, seja

(38) Na terminologia do Direito Internacional, tratado, convençāo, acordo, pacto, protocolo ou qualquer outra denominação para significar um ato escrito e solene entre Estados, regido pelo Direito Internacional, com o fito de criar direitos e deveres internacionais entre eles, são sinônimos. Dai por que se utiliza, em geral, a expressão "tratados e convençōes internacionais". Veja-se a Convenção de Viena sobre Direito dos Tratados, firmada em 23/5/1969, em vigor internacional a partir de $27 / 1 / 1980$, a qual foi assinada pelo Brasil, mas ainda não se encontra vigente na ordem juridica interna brasileira, e, portanto, ainda nāo foi ratificada pelo País. Texto apud Vicente Marotta Rangel, "Direito e Relaçōes Internacionais", $5^{\circledR}$ ed. revista $\theta$ atualizada, São Paulo, Revista dos Tribunais, 1997, pp. 297/334.

(39) No caso da Organização Internacional do Trabalho, as normas votadas na sua Assembléia Geral sobre assuntos de sua competência denominam-se "convençōes internacionais do traba- 
por proposta de uma organização intergovernamental (por exemplo: a Convenção sobre a Diversidade Biológica, assinada no Rio de Janeiro em junho de 1992, no curso da Conferência das Nações Unidas sobre Meio Ambiente e Desenvolvimento, a denominada ECO/92); inexiste um tratado ou convenção internacional após 1945 que tenha sido assinado sob a égide da OMS (devendo-se observar que não se deve confundir tais convenções com aquelas outras que, conquanto versem sobre matéria sanitária, por exemplo, as convençōes sobre estupefacientes, foram negociados em outros foros, como a Comissão de Estupefacientes da ONU, sendo a OMS simplesmente consultada sobre matéria técnica). Quanto a "acordos", conforme ainda a Constituição da OMS, se forem entendidos como atos normativos firmados entre organizações intergovernamentais, há vários, entre a OMS, a OIT, a AIEA, a OPS, etc., e, se forem firmados entre a OMS e um Estado (por exemplo: o acordo de sede com o Governo suiço), são, como os primeiros, atos bilaterais, firmados entre duas pessoas jurídicas de Direito Internacional;

b) "recomendações" são as decisões coletivas tomadas pela Assembléia Mundial da Saúde, portanto atos unilaterais de Direito Internacional (porque atos expedidos por uma pessoa jurídica de Direito Internacional, a OMS), endereçados "aos Estados membros relativamente a todo assunto que seja da alçada da Organização" (art. 23 da Constituição). Inexiste dispositivo na Constituição quanto a quorum de deliberação em matéria de recomendações (portanto, maioria dos votos normativos). Trata-se de atos normativos equivalentes a um conselho endereçado aos Estados membros, e, conforme apontado pelo Prof. Michel Bélanger (ob. cit., p. 71), podem assumir dois graus de importância: a) solicitaçōes aos Estados para adotarem certas medidas de caráter sanitário no seu ordenamento jurídico interno (por exemplo: medidas de proteção contra moléstias transmissiveis, ou medidas contra a poluição, nas suas várias formas) e b) transmissão aos Estados de inteiros códigos de conduta, normas já prontas, ou princípios diretivos em matéria sanitária, com a finalidade de os Estados os adotarem em sua legislação interna (por exemplo: o código internacional de substitutivos do leite materno, adotado em maio de 1981 pela $34^{a}$ Assembléia Mundial da Saúde). Embora não tenham a mesma força obrigatória aos Estados que os tratados e convenções internacionais típicos, as resoluções da OMS cumprem a importante tarefa de harmonizar ou, pelo menos, representar o mais elevado padrão de normas sanitárias, em nível internacional, que, por sua autoridade científica e técni$\mathrm{ca}$, se impõem aos legisladores e às autoridades administrativas internas dos Estados, como modelos, e, enfim, acabam por ser adotadas

Ino". Note-se que, no Direito das Organizaçōes internacionais, é necessário examinar, caso a caso, cada organizaçāo intergovernamental, para descobrir a denominação dos atos que expedem e sua respectiva força normativa. 
como normas nacionais na maioria dos países. Outro tipo de recomendações expedidas pela OMS diz respeito à competência que lhe foi atribuida (na verdade, ao Diretor-Geral e não à Assembléia Mundial da Saúde) por duas convenções internacionais, adotadas sob a égide da Assembléia Geral da ONU: a Convenção Única sobre Estupefacientes de 1961 e a Convenção sobre Substâncias Psicotrópicas de 1971 (avaliação quanto a efeitos sanitários de substâncias químicas e indicação da necessidade de seu controle interno ou internacional);

c) "regulamentos" são os atos mais típicos da OMS, e, como as recomendações, trata-se de atos internacionais expedidos por uma organização intergovernamental, a OMS (na verdade, como se disse, são atos unilaterais internacionais expedidos por uma pessoa juridica de Direito Internacional, conquanto sejam adotados num foro multilateral), no exercício de sua competência naquelas matérias indicadas no art. 21 da Constituição, concernentes, verbis: a) às medidas sanitárias e de quarentena ou a qualquer outro processo com o fim de impedir a propagação de doenças de um país a outro; b) à nomenclatura das doenças, das causas de óbito e dos métodos de higiene pública; c) a padrões com respeito a processos de diagnósticos para uso internacional; d) a padrões relativos à garantia; pureza e atividade dos produtos biologicos, farmacêuticos e similares que se encontram no comércio internacional; e) à publicidade e nomenclatura dos produtos biológicos farmacêuticos e similares que se encontram no comércio internacional. A OMS expediu, até o momento, apenas dois regulamentos sanitários internacionais, cada um várias vezes emendado: um, o Regulamento sobre a Nomenclatura, ou seja, em matéria de classificação internacional das doenças, traumatismos e causas de mortalidade (denominado "classificação de moléstias", CIM), e outro, o Regulamento Sanitário destinado a prevenir e tratar as doenças pestilenciais.

Um importante fato a respeito dos regulamentos da OMS diz respeito a entrarem em vigor, na esfera internacional, na data de sua adoção pela Assembléia Mundial da Saúde e, portanto, independentemente de qualquer providência de os Estados confirmarem sua aceitação e/ou de informarem sobre sua incorporação nos respectivos ordenamentos internos ${ }^{(40)}$. É o que

(40) No caso dos tratados e convençóes internacionais solenes, a regra mais usual é de que os atos internacionais somente entram em vigor, na esfera internacional, em relaçāo a um Estado signatário, no momento em que este deposita um instrumento de ratificação (ou seja, confirma aos outros signatários sua intenção de, realmente, aceitar os direitos e deveres anteriormente assumidos). A ratificação é uma confirmação e. modernamente, significa uma certificaçāo de que o tratado ou convenção recebeu a aprovaçāo dos Poderes Legislativos internos, portanto, acha-se conforme à legislação interna dos Estados. Há, contudo, tratados e convenções menos solenes, que entram em vigor internacional por outros modos e sem as formalidades da ratificação. 
resulta dos dispositivos do art. 22 da Constituição da OMS, verbis: "Os regulamentos anotados para a execução do artigo 21 entrarão em vigor para todos os Estados membros, uma vez devidamente notificada sua adoção pela Assembléia da Saúde, exceto para os membros que, dentro dos prazos determinados na notificação, tenham comunicado ao Diretor-Geral a sua recusa ou reserva que Ihes opõem". Tais dispositivos, no Direito Internacional das Organizações Internacionais clássico(41), existem unicamente na OMS e na OIT, ou seja, de uma incorporação automática dos atos normativos da organização intergovernamental, nos ordenamentos jurídicos internos dos Estados, no caso da OMS, a menos no caso de uma recusa ou reserva formalmente apresentada por estes em sentido contrário.

Na verdade, a tarefa de uniformizar, em nivel internacional, as normas técnicas sobre o combate às moléstias pestilenciais foi uma das primeiras urgências que a recém-instalada OMS teve de enfrentar, sobretudo à vista da situação calamitosa em que os serviços nacionais de saúde pública se encontravam na Europa e na Ásia, continentes nos quais as principais hostilidades bélicas se tinham desenrolado. Já nos referimos às epidemias de tifo e de todas aquelas doenças que acompanham situações calamitosas em nível mundial. Por outro lado, tão logo restabelecida a paz, do ponto de vista técnico, no que respeita a sua competência normativa em matéria sanitária intemacional, a OMS se deparava com uma situação caótica, conforme bem descreveu o Prof. Claude-Henri Vignes, pois, na primeira metade do século $X X$, mais de 10 instrumentos internacionais, que estavam em vigor, tratavam praticamente das mesmas questões sanitárias, em diplomas normativos que não se revogavam reciprocamente, e, o que era mais embaraçoso, que não se aplicavam aos mesmos Estados, pelo fato de estes não serem partes, ao mesmo tempo, em todos aqueles diplomas internacionais. Dentre estes, aquele Professor cita, verbis: "a convenção sanitária de 1903... a convenção sanitária panamericana assinada em 1905... uma nova convenção sanitária internacional datada de 1912, o código sanitário panamericano, redigido em 1924... em 1926, a convenção sanitária internacional sobre a navegação maritima; em 1933, a convenção sanitária internacional para a navegação aérea, em 1954, os dois ajustes internacionais sobre as cartas patentes de saúde" ("Le Règlement Sanitaire Internacional: Aspects Juridiques", in Anuaire Français de Droit International, 1965, p. 651). No dizer daquela autoridade: "tornava-se indispensável uniformizar e racionalizar tal regulamentação" (id., ibid., bis ibid.).

Tratava-se, portanto, da obra de consolidação de uma legislação esparsa, mas, sobretudo, de uma codificação de regras novas, que, à luz dos

(41) No moderno Direito Internacional da Integração Económica Regional, em particular no caso dos modelos mercado-comum, como a Comunidade Européia, em matéria de direitos econômicos, há outras modalidades de internalização automática das normas votadas pelos órgăos supranacionais comunitários, nos ordenamentos internos dos Estados-Partes: o regulamento e as decisões do Conselho de Ministros e da Comissăo entram em vigor nos ordenamentos jurídicos internos daqueles Estados, independentemente de qualquer providencia por parte das autoridades legislativas internas; as diretivas necessitam de um ato normativo dos Estados-membros, a fim de que possam ser incorporadas aos respectivos ordenamentos juridicos internos. 
conhecimentos científicos e da realidade dos fatos existentes naquele momento histórico, se tornava urgente: tal realidade nova eram, de um lado, as premências dos novos problemas suscitados por questões das migrações forçadas, durante e no pós-guerra, mas, sobretudo, a maior freqüência de movimento internacional de pessoas e mercadorias em tempo de paz, e, de outro lado, os extraordinários progressos dos conhecimentos científicos e das práticas terapêuticas preventivas e curativas, no relativo a doenças infecciosas transmissíveis, em especial às moléstias quarentenárias pestilenciais. No imediato pós-guerra, a preocupação era, portanto, um "aggiornamento" e a colocação de ordem num futuro regulamento sanitário internacional, que deveria, então, contemplar a prevenção e o tratamento da peste, da cólera, do tifo exantemático, da febre amarela, da febre recorrente e da variola.

Um primeiro Regulamento Sanitário Internacional seria adotado em 25 de maio de 1951, bastante detalhado, e no qual se contemplavam as seis moléstias pestilenciais mencionadas. Várias modificações foram feitas, algumas no sentido de retirar algumas doenças daquele Regulamento (como foi o caso da variola, que foi em 1987 declarada erradicada(42), e da cólera, que teve sua regulamentação abrandada, no sentido de restringir as obrigações de vacinações compulsórias nos casos de viagens internacionais a determinados países). Um segundo Regulamento Sanitário Internacional seria adotado em 25 de julho de 1969, este complementado por um Regulamento Adicional votado em 23 de maio de 1973, sendo que, na atualidade, unicamente a peste, a cólera e a febre amarela são consideradas moléstias quarentenárias. Por outro lado, é necessário dizer que existem Protocolos ao Regulamento Sanitário Internacional, por países, onde se definem as moléstias transmissiveis de maior ocorrência, com as medidas profiláticas e de tratamento adequadas.

Na verdade, em que pesem as grandes virtudes do Regulamento Sanitário Internacional, basicamente, em primeiro lugar, a informação e disseminação internacional de dados científicos, técnicos e estatísticos, e, em segundo, a normalização indireta, em nível mundial, de técnicas terapêuticas e de prevenção, através de uma relativa uniformização e harmonização das legislações internas dos Estados, há críticas sobre a sua utilidade. Ressaltese sua relativa inflexibilidade, em face da velocidade dos conhecimentos científicos e técnicos na área de profilaxia e tratamento, ou, mesmo, em relação a uma reversão de certas tendências (recorrência de moléstias tidas como extintas enquanto epidêmicas, como no caso da varíola); por outro lado, a ênfase dada ao conceito de "doença" contrasta com a tendência atual das Ciências da Saúde de considerar antes "a pessoa doente"; enfim, há a consciência de que se torna cada vez mais importante realçar o conceito de luta antivetorial nas situações epidemiológicas. 
Outras importantes atividades normativas da OMS dizem respeito ao controle internacional de medicamentos. Neste particular, dedica-se ela a estudos e recomendações no que respeita a denominações comuns internacionais, a questões relativas a procedimentos conducentes a uma estandardização de produtos biológicos e farmacêuticos, ao estabelecimento de padrões de qualidade com vistas ao controle da qualidade de medicamentos, e, enfim, a tarefa de extrema relevância para os países em desenvolvimento, ou seja, a definição dos medicamentos essenciais.

\section{CONCLUSÓES E A APRESENTAÇĀO DOS INCÔMODOS VIZINHOS DO DIREITO INTERNACIONAL SANITÁRIO: A LIBERDADE DO COMÉRCIO INTERNACIONAL E A PROTEÇÃO INTERNACIONAL AO MEIO AMBIENTE}

Um estudo dos grandes temas do Direito Internacional Sanitário, mesmo que superficial, como o presente, não poderia deixar de mencionar, igualmente, as grandes discussões e as perplexidades que o cercam. Nem tanto pelo Direito Internacional Sanitário, por ele mesmo, pois se trata de uma conquista civilizatória na história da humanidade, em particular se levarmos em consideração o traço característico da atualidade normativa internacional: o dever dos Estados de cooperação, para conseguir um melhor nível de saúde e bem-estar, em nivel global, independentemente do status de desenvolvimento econômico, mas por outros ramos do Direito Internacional, vizinhos do Direito Internacional Sanitário, onde valores outros, tão relevantes como o direito à vida e à saúde, podem entrar em conflito com aqueles protegidos pelo Direito Internacional da Saúde.

Historicamente, como se pode observar pela emergência do próprio Direito Internacional Sanitário, já havia, nas primeiras normas das cidades venezianas do século XIII, uma oposição entre as medidas de luta contra a peste, importada do Oriente Médio, e as necessidades de salvaguardar a liberdade do comércio marítimo. Embora não se conhecessem as causas de uma moléstia transmissível, já se tinha noção de que seus vetores eram pessoas que visitavam ou que vinham de outros lugares, autênticos importadores de males desconhecidos, mas igualmente os agentes do comércio internacional, portanto igualmente vetores de riquezas. Tanto assim que as medidas de interdição total do comércio ou de viagens internacionais eram afastadas, em benefício da criação de lazaretos e de períodos de quarentena a viajantes (e, muito posteriormente, a mercadorias).

$\mathrm{Na}$ verdade, medidas sanitárias impositivas, quando aplicadas a navios ou comerciantes estrangeiros, naqueles tempos, como nos atuais, podem, como já se observou, mascarar medidas protecionistas, que, na maioria dos casos, ensejam medidas retaliatórias por parte de outros Estados, criando-se, assim, situações de extrema tensão nas relações comerciais e 
econômicas. O equilibrio entre, de um lado, as necessidades de controles fortes da saúde pública, que podem, segundo as circunstâncias, direcionar o comércio internacional, em favor de parceiros ou clientes mais favorecidos, e, de outro, a liberdade nas relações internacionais de comércio será sempre um desafio à harmonia internacional, em particular quando o mundo se acha submetido a regras que pretendem garantir a citada liberdade e a transparência no comércio e na economia globais.

Se uma das características do Direito Internacional do século $X X$ tem sido a necessidade da cooperação internacional, políticas protecionistas e, 0 que é pior, políticas discriminatórias contra determinados Estados, representaria a negação daquele espírito. Se o Direito Internacional Sanitário ganhou as coloraçōes que hoje possui, devido à sua tintura com as cores dos deveres de cooperação entre os Estados, a regulamentação, no mesmo século XX, das relações econômicas e comerciais entre os Estados, igualmente tingidas com as mesmas cores, não deveria, em princípio, entrar em conflito com ele. Contudo, não é o que se ọbserva.

A regulamentação da liberdade do comércio internacional, no século XX, se acha, após a Segunda Guerra Mundial, marcada pelo princípio da multilateralização automática da cláusula da nação mais favorecida, que, brevitatis causa, ficou conhecido como "cláusula da nação mais favorecida". Expliquemo-nos: nos séculos anteriores, todos os tratados internacionais de comércio e mesmo as relações comerciais internacionais informais se achavam contaminados por uma cláusula, imaginada pela Inglaterra, de que ela, em todos os portos e economias do mundo, teria um tratamento mais favorável, da mesma forma que os produtos e comerciantes vindos do parceiro não inglês receberiam idêntico tratamento nos portos e na economia do Reino Unido. Sem dúvida que a reciprocidade beneficiava os parceiros da Inglaterra e ela mesma, em qualquer parte do mundo, mas tais benefícios năo eram estendidos a outros países ou a outros comerciantes. Tais cláusulas, ou princípio, da nação mais favorecida, se davam à Inglaterra uma situação de monopólio do comércio internacional, por outro lado, impediam que uma situação privilegiada fosse estendida a terceiros Estados (reforçando, portanto, situaçōes de dominação e de exclusão de terceiros, numa negação da liberdade do comércio internacional). Com a criação do GATT, em 1955, e sua posterior transformação na Organização Mundial do Comércio, em 1995, o que os Estados determinaram foi que, na eventualidade de haver cláusulas de nação mais favorecida, estas seriam, de maneira automática, estendidas a todos os Estados Partes naquelas organizações internacionais (portanto, com o efeito de anular qualquer benefício discriminatório entre Estados, uma vez que os benefícios reciprocos entre parceiros seriam estendidos a quaisquer outros Estados). Portanto, na sua legislaçāo interna e na sua prática administrativa de importação e exportação, os Estados não poderiam mais discriminar produtos de certos Estados, seja determinando proibições de entrada de certos 
produtos, seja determinando quantidades permitidas, seja ainda impondo tributos discriminatórios a determinados produtos, uma vez que o denominado princípio da cláusula da nação mais favorecida proibia qualquer medida discriminatória de natureza tarifária (medidas tributárias consistentes em impostos ou taxas) ou medidas não tarifárias (controles de quantidades ou de qualidades dos produtos, dentre os quais se destacam as medidas de controles sanitários).

Contudo, havia, como continua havendo, exceções para situações de emergência, tais como um grave desequilíbrio no balanço de pagamentos ou situações de perigo à saúde pública, situações essas que permitem a um Estado como que esquecer de suas obrigações internacionais, e, portanto, voltar, temporariamente, a recriar as discriminações contra determinados produtos ou contra determinados Estados. Ao final da Rodada Uruguai do GATT, longa negociação internacional da qual sairia constituída a OMC, os Estados adotaram uma série de normas de exceção ao princípio da cláusula da nação mais favorecida, devendo destacar-se o Acordo sobre a Aplicação de Medidas Sanitárias e Fitossanitárias, pelo qual se define a regra de que "nenhum Membro deve ser impedido de adotar ou aplicar medidas necessárias à proteção da vida ou da saúde humana, animal ou vegetal, desde que tais medidas não sejam aplicadas de modo a constituir discriminação arbitrária ou injustificável entre Membros em situações em que prevaleçam as mesmas condições, ou uma restrição velada ao comércio internacional" (43).

Uma pergunta poderia esclarecer a questão, a partir do exame de um caso realmente acontecido: porventura as proibições dos EUA de importação da gasolina brasileira e venezuelana, alegadamente porque continham uma mistura de enxofre que contrariava os padrões norte-americanos, eram motivadas por razões sanitárias de controle da qualidade do ar, ou antes representavam medidas protecionistas à gasolina produzida naquele país? A resposta da OMC foi de que aquelas restrições eram de ordem comercial, portanto discriminatórias e proibidas por essa organização, $\theta$, sendo assim, ilegais (e os EUA foram condenados a pagar determinado montante de perdas que os exportadores brasileiros e venezuelanos sofreram, montante esse cobrado em concessões unilaterais a produtos brasileiros e venezuelanos, até o limite das perdas apuradas).

Se tais fenômenos se verificam no comércio internacional em geral, ainda mais forte são as proibições de discriminação entre Estados que se encontram irmanados numa comunidade internacional, resultante de um tratado internacional de integração econômica regional: o principio da proibição de discriminação se torna ainda mais cogente na medida em que os Estados aceitaram obrigações de agir em comum, dentro de um bloco inte-

(43) Texto conforme o Decreto n. 1.355, de 30/12/1994 (publicado no Diário Oficial da Uniăo de 31/ 12/1994), que promulgou no Brasil os "Resultados da Rodada Uruguai do GATT". Veja-se: "Resultados da Rodada Uruguai do GATT", São Paulo, Aduaneiras, 1995. 
grativo econômico, seja em relação aos parceiros (proibições de práticas protecionistas no interior de uma organização de integração econômica regional), seja ainda em relação a terceiros (ou seja, os parceiros dos Estados Partes de uma organização de integração econômica regional, cujas políticas comerciais devem estar conformes às dos outros Estados Partes, para evitar uma concorrência internacional predatória com reflexos no conjunto daquela organização). Não é por outra razão que o Direito Internacional Sanitário se encontra em todas as organizações regionais de integração econômica regional, cujo exemplo mais acabado é a situação das regras de saúde pública, que se acham no centro da Comunidade Européia. Os controles de sanidade pública, em particular no que respeita ao comércio, são normas que tendem a ser supranacionais, na Europa comunitária, nem tanto por motivos de uniformização e harmonização das legislações nacionais, mas muito mais para uniformizar e harmonizar práticas comerciais. As discussões sobre a sanidade do queijo camembert, o que se define como cerveja ou champagne ou cognac, ou ainda os problemas da "vaca louca", se na sua aparência podem aparecer como controles sanitários ou de produtos, no fundo se trata de controles sobre a comercialização no interior da Comunidade Européia.

No MERCOSUL, há dificuldades de estabelecer um controle sanitário comum entre os parceiros, nem tanto porque a saúde do brasileiro, argentino, paraguaio ou uruguaio sejam realidades distintas, mas por razões econômicas bastante compreensiveis, de querer conservar padrões nacionais, talvez mais exigentes em matéria de saúde, mas, igualmente, mais tendentes a privilegiar produtos nacionais em detrimento daqueles provindos dos parceiros.

Por outro lado, o Direito do Comércio Internacional, em particular aquele que se desenvolve na Organização Mundial do Comércio, desde os tempos do antigo GATT, tem uma particularidade que o distingue de qualquer outro ramo do Direito Internacional: possui garras e dentes afiados! Uma violação das normas da OMC-GATT ${ }^{(44)}$, conforme o exemplo relatado anteriormente, no caso da gasolina modificada e das proibiçōes dos EUA, se formalmente verificada por procedimentos existentes naquela organização internacional (já existentes no antigo GATT e que foram aperfeiçoados na OMC), sujeitam - Estado violador a retaliações temporárias do Estado vítima, até um montante em que os prejuízos sejam cobertos; tais retaliações consistem na suspensão das proibições de discriminação a determinado Estado, permitindose, assim, ao Estado vítima impor taxas, tributos e outras medidas não tarifárias de natureza discriminatória contra o Estado violador. Ora, se o Direito

(44) Veja-se, nāo a propósito das normas do Direito Internacional Sanitário, mas das normas de proteção da propriedade intelectual, as implicaçōes de um assunto entrar no campo da temática do GATT-OMC, nosso artigo: "O Tratamento de Propriedade ..." cit., pp: 98/119. 
Internacional Sanitário, cuja efetividade parece tão fraca, uma vez que não dispõe de mecanismos para compelir os Estados a aplicarem suas normas, quando unido ao Direito do Comércio Internacional pode aproveitar-se de tais mecanismos sancionatórios das normas neste existentes, pode, igualmente, vir a sofrer sanções de ordem econômica, caso venha a conflitar com ele!

Outra vizinhança incômoda do Direito Internacional Sanitário é o Direito Internacional do Meio Ambiente. Neste particular, os conflitos advêm das ligações existentes entre o Direito Sanitário e as normas de proteção internacional dos direitos humanos. No fundo, existe um contraste entre as concepções filosóficas do conceito "vida", que, ao ver tradicional dos Direitos Humanos, centrar-se-ia numa mundivisão antropocêntrica exacerbada da realidade. Ora, o Direito Internacional do Meio Ambiente argúi que há outras formas de vida que merecem proteção, além da vida humana! Tenha-se presente que a própria Assembléia Geral da ONU proclamou: "Qualquer vida é única e merece ser respeitada, pouco importando sua utilidade para o homem, e, a fim de reconhecer aos outros organismos vivos este valor intrínseco, o homem deve guiar-se por um código moral de ação" (Preâmbulo da Carta Mundial da Natureza, AG da ONU, 28/10/1982)!

Tenha-se presente, igualmente, o fato de que qualquer ocupação humana do mundo significa uma transformação do meio ambiente, inclusive destruição ou modificações de paisagens naturais, como o saneamento de áreas insalubres ao homem, mas importantes hoje de serem preservadas, porque são hábitats de outros animais. Neste particular, os pântanos, char$\cos$, áreas naturalmente inundadas, que são o hábitat de mosquitos portadores de doenças (os antigos romanos acreditavam que a doença que infestava os locais próximos aos pântanos era devida aos maus ares, "mala aria", que aqueles lugares exalavam!), são, igualmente, o hábitat de animais protegidos por normas internacionais (no caso, a Convenção de Ramsar relativa a Zonas Úmidas de Importância Internacional, Particularmente como Hábitat das Aves Aquáticas, de 1971, vigente no Brasil, e altamente relevante para nós, à vista da necessidade de preservar o Pantanal Matogrossense).

Não nos parece tão natural uma aproximação entre os direitos humanos e o meio ambiente, mesmo que se procure encontrar um elemento comum entre ambos: a vida humana! Nossa perplexidade se encontra estampada no trabalho Direitos Humanos e Meio Ambiente, que deverá ser um capítulo do "Livro em Comemoração ao Cinqüentenário da Declaração Universal dos Direitos Humanos", a ser editado pela Editora da Universidade de São Paulo, sob a responsabilidade dos Prof. Dr. Alberto Amaral Júniore Dra. Cláudia Perrone Moisés, ambos do Departamento de Direito Internacional da Faculdade de Direito da USP (no prelo). 
Tal perplexidade se junta a outra: a magnitude das tarefas daqueles que buscam aventurar-se num campo tão rico e tão relevante como o Direito Internacional Sanitário. Esperamos, assim, haver dado nossa contribuição, pelo menos, ao aflorar os grandes temas deste ramo particular do Direito Internacional e, provocativamente, enunciar sua incômoda vizinhança.

\section{REFERÊNCIAS BIBLIOGRÁFICAS}

Académie de Droit International de la Haye et Université des Nations Unies, Colloque 1978 (27-29 juillet 1978), Le Droit à la Santé en tant que Droit de l'Homme, Alphen aan den Rijn, Sijthoff \& Noordhoff, 1979.

Académie de Droit International de la Haye, Colloque 1973 (14-16, VIII), La Protection de l'Environnement et le Droit International, The Protection of the Environment and International Law, Leyden, Sijthoff, 1975.

, Colloque 1984 (12-14, XI), L'Avenir du Droit International de l'Environnement, The Future of the International Law of the Environment, Dordrecht, Boston, Lancaster, Martinus Nijhoff, 1965.

Accioly, Hildebrando, "Tratado de Direito Internacional Público", $2^{\mathrm{a}}$ ed., Rio de Janeiro, Gráfica do IBGE, 1956, vol. III.

Beigbeder, Yves, "Le Rôle International des Organisations Non Gouvernementales", Paris, Bruxelas, Bruylant, LGDJ, 1992.

Bélanger, Michel, "Droit International de la Santé", Paris, Economica, 1983.

Bowett, D. H., "The Law of International Institutions", $3^{\text {a }}$ ed., London, Stevens \& Sons, 1975.

Cançado Trindade, Antonio Augusto, "Meio Ambiente e Desenvolvimento: Formulação e Implementação do Direito ao Desenvolvimento como um Direito Humano", in Boletim da Sociedade Brasileira de Direito Internacional, ano XLV, jul./nov. de 1992, n. 81/83, pp. $49 / 76$.

Colliard, Claude-Albert, "Institutions des Relations Internationales", 6* ed., Paris, Dalioz, 1974.

Dreyfuz, Simone, "Droit des Relations Internationales, Éléments de Droit International Public", 4" ed. revista e aumentada, Paris, Cujas, 1992.

Fonseca, Valéria Simões Lira da, "O Direito Internacional face à Saúde e às Moléstias Transmissíveis", Dissertação de Mestrado defendida em 17/6/ 1990, Faculdade de Direito da USP.

McWhinney, Edward, "Le Concept de Coopération", apud Mohammed Bedjaoui, redator-geral, "Droit International, Bilan et Perspectives", Paris, Editions A. Pedonne, UNESCO, 1991, t. 1, pp. 445 e ss. 
Rangel, Vicente Marotta, "Direito e Relações Internacionais", $5^{\text {" }}$ ed. revista e atualizada, São Paulo, Revista dos Tribunais, 1997.

Schermers, Henry G. e Niels M. Blokker, "International Institutional Law", Londres, Boston, Haia, Martinus Nijhoff Publishers, 1995.

Soares, Guido F. S., "A Cooperação Técnica Internacional", apud Jacques Marcovitch (org.), Cooperação Internacional: Estratégia e Gestão, São Paulo, Editora da Universidade de São Paulo, 1994, pp. 165/218.

"Antecedentes da Transferência Internacional de Tecnologia", in Revista de Direito Mercantil, São Paulo, ano 24, jan./mar. 1985, pp. 19 e ss.

, "As Responsabilidades no Direito Internacional do Meio Ambiente", Tese para Professor Titular de Direito Internacional Público, 1995, Faculdade de Direito da USP.

"Contribuição ao Estudo da Política Nuclear Brasileira", Tese de Doutoramento em Ciências Humanas (Política Internacional), PUCSP, 1974.

Direitos Humanos e Meio Ambiente, capítulo do "Livro em Comemoração ao Cinqüentenário da Declaração Universal dos Direitos Humanos", a ser editado pela Editora da Universidade de São Paulo, sob a responsabilidade do Prof. Dr. Alberto Amaral Júniore da Dra. Cláudia Perrone Moisés, Departamento de Direito Internacional da Faculdade de Direito da USP (no prelo).

"International Trade and Environment: Confrontation between the WTO/GATT and Environmental Protection Norms", in Trade and Environment Revisited: Multilateral Negotiation Scenarios in a Southern Perspective, a ser editado pela United Nations University (no prelo). [TrabaIho resultante do Multilateral Diplomacy Seminar - MERCOSUR (São Paulo and Florianópolis, nov./dec., 1997), patrocinado pela Universidade das Nações Unidas.]

, "O Meio Ambiente e a Justiça no Mundo Globalizado", in Justiça Penal, Críticas e Sugestōes, 10 Anos da Constituição e a Justiça Penal, São Paulo, Revista dos Tribunais, 1999, pp. 65/118.

, "Os Órgãos das Relações Exteriores dos Estadós e as Formas de Diplomacia na Atualidade", in Revista da Faculdade de Direito da USP (no prelo).

"O Tratamento de Propriedade Intelectual no Sistema da Organização Mundial do Comércio - Uma Descrição Geral do Acordo 'TRIPS'", in Revista de Direito Civil, Imobiliário, Agrário e Empresarial, São Paulo, Faculdade de Direito da USP, 1995, pp. 98/119. 
Vignes, Claude-Henri, "Le Règlement Sanitaire International: Aspects Juridiques", in Anuaire Français de Droit International, 1965, pp. 649/667. "Problèmes juridiques récents posés à IOMS", in Annuaire Français de Droit International, 1963.

Vitta, Cino, "Droit Sanitaire International", in Recueil des Cours, Haia, 1933, vol. 33, pp. 546/667.

White, N. D., "The Law of International Organisations", Manchester e Nova York, Manchester University Press, 1996.

Zarb, Antoine H., "Les Institutions Spécialisées du Système des Nations Unies et Leurs Membres", Paris, Édition Pedonne, 1980. 